\title{
Detection of Microorganisms in Granulomas That Have Been Formalin-Fixed: Review of the Literature Regarding Use of Molecular Methods
}

\author{
Jeannette Guarner \\ Department of Pathology and Laboratory Medicine, Emory University, Atlanta, GA 30322, USA \\ Correspondence should be addressed to Jeannette Guarner; jguarne@emory.edu
}

Received 19 November 2012; Accepted 11 December 2012

Academic Editors: G. Marucci and D. Sanglard

Copyright (C) 2012 Jeannette Guarner. This is an open access article distributed under the Creative Commons Attribution License, which permits unrestricted use, distribution, and reproduction in any medium, provided the original work is properly cited.

\begin{abstract}
Granuloma is an organized aggregate of immune cells that under the microscope appear as epithelioid macrophages. A granuloma can only be diagnosed when a pathologist observes this type of inflammation under the microscope. If a foreign body or a parasite is not observed inside the granuloma, stains for acid-fast bacilli and fungi are ordered since mycobacteria and fungi are frequently the cause of this type of inflammation. It is calculated that 12 to $36 \%$ of granulomas do not have a specific etiology and many have wondered if with new molecular methods we could reduce this number. This paper will summarize the frequently known causes of granulomas and will present the recent literature regarding the use of molecular techniques on tissue specimens and how these have helped in defining causative agents. We will also briefly describe new research regarding formation and function of granulomas and how this impacts our ability to find an etiologic agent.
\end{abstract}

\section{Introduction}

Granuloma is an organized aggregate of immune cells that under the microscope appear as epithelioid macrophages [1]. Epithelioid macrophages are enlarged phagocytic cells that have abundant cytoplasm and can sometimes coalesce to form multinucleated giant cells. The epithelioid macrophages and giant cells are accompanied by other inflammatory cells including lymphocytes, plasma cells, and polymorphonuclear leukocytes as well as varying degrees of necrosis. The process may be confined forming a granuloma or can infiltrate surrounding tissue thus being called granulomatous inflammation. This chronic inflammatory response has been attributed to delayed hyperimmune reaction to a persistent noxious stimulus. Traditionally, granulomatous inflammation is thought to wall of the noxious agent. However, new experimental observations in the formation of granulomas are now emerging and giving new insides as to how they form and if in reality they are encasing the agent that causes them.

A granuloma or granulomatous inflammation can only be diagnosed when a pathologist observes this type of inflammation under the microscope. If a foreign body or a parasite is not observed inside the granuloma, stains for acid-fast bacilli (AFB) and fungi (GMS) are ordered as mycobacteria and fungi are frequently the cause of this type of inflammation. There are other diagnostic entities that need to be entertained depending on the tissue, but it is customary to rule out mycobacteria and fungi first before considering other diagnostic possibilities. It is calculated that 12 to $36 \%$ of granulomas do not have a specific etiology $[2,3]$ and many have wondered if with new molecular methods we could reduce this number. This paper will summarize the frequent known causes of granulomas and review the recent literature regarding the use of molecular techniques on tissue specimens that have helped in diagnosing the cause. We will also briefly describe new research regarding formation and function of granulomas and how this impacts our ability to find an etiologic agent.

\section{Causes of Granulomas}

From the morphologic perspective, granulomas can present different amounts of necrosis, different sizes and shapes (stellate or geographic), different amounts and types of accompanying inflammatory cells (suppurative, plasma cells), or 
TABLE 1: Etiologic causes of granulomas depending on the histopathologic characteristic.

\begin{tabular}{|c|c|c|}
\hline Characteristic of granuloma & Description & Etiologic causes \\
\hline With necrosis & $\begin{array}{l}\text { Macrophages, multinucleated giant cells, } \\
\text { lymphocytes, and central necrosis; calcifications may } \\
\text { be present }\end{array}$ & $\begin{array}{l}\text { Tuberculosis, chronic fungal infections (such as } \\
\text { histoplasmosis, coccidioidomycosis, } \\
\text { blastomycosis), Wegener's granulomatosis }\end{array}$ \\
\hline $\begin{array}{l}\text { With necrosis and } \\
\text { eosinophils }\end{array}$ & $\begin{array}{l}\text { Macrophages, multinucleated giant cells, } \\
\text { lymphocytes, eosinophils, and necrosis }\end{array}$ & $\begin{array}{l}\text { Parasites (including schistosomiasis, fasciolosis), } \\
\text { sometimes some of the chronic fungal infections } \\
\text { mentioned above }\end{array}$ \\
\hline $\begin{array}{l}\text { With stellate or geographic } \\
\text { necrosis }\end{array}$ & $\begin{array}{l}\text { Macrophages, multinucleated giant cells, } \\
\text { lymphocytes, neutrophils, central necrosis that takes } \\
\text { a stellate shape }\end{array}$ & $\begin{array}{l}\text { Tularemia, bartonellosis, lymphogranuloma } \\
\text { venereum, actinomycosis, chronic granulomatous } \\
\text { disease }\end{array}$ \\
\hline $\begin{array}{l}\text { With suppurative } \\
\text { inflammation }\end{array}$ & $\begin{array}{l}\text { Macrophages, lymphocytes, abundant neutrophils, } \\
\text { and different amounts of necrosis }\end{array}$ & Tularemia, listeriosis, acute fungal infections \\
\hline With abundant plasma cells & $\begin{array}{l}\text { Macrophages, multinucleated giant cells, } \\
\text { lymphocytes, plasma cells, and different amounts of } \\
\text { necrosis }\end{array}$ & Syphilis \\
\hline $\begin{array}{l}\text { Foamy macrophage } \\
\text { aggregates }\end{array}$ & $\begin{array}{l}\text { Foamy macrophages with minimal necrosis and } \\
\text { other inflammatory cells }\end{array}$ & $\begin{array}{l}\text { Atypical mycobacteria (MAI), Whipple disease, } \\
\text { Rhodococcus equi, lepromatous leprosy }\end{array}$ \\
\hline $\begin{array}{l}\text { Epithelioid granuloma with } \\
\text { minimal or no necrosis }\end{array}$ & $\begin{array}{l}\text { Small, macrophages, multinucleated giant cells, } \\
\text { lymphocytes }\end{array}$ & Leishmaniasis, sarcoidosis, lupus, hepatitis C \\
\hline $\begin{array}{l}\text { Epithelioid granuloma with } \\
\text { minimal or no necrosis but } \\
\text { presence of eosinophils }\end{array}$ & $\begin{array}{l}\text { Small, macrophages, multinucleated giant cells, } \\
\text { lymphocytes, eosinophils }\end{array}$ & Rejection after transplant, response to medications \\
\hline Ill defined & Small groups of macrophages & Hodgkin's disease, metastasis \\
\hline Lipid granulomas & $\begin{array}{l}\text { Macrophages with lipid vacoules, lymphocytes, may } \\
\text { have some necrosis including fibrin deposition }\end{array}$ & $\begin{array}{l}\text { Lipid containing foods, mineral oils, reactions to } \\
\text { medications, toxoplasmosis }\end{array}$ \\
\hline $\begin{array}{l}\text { Granulomas with a vacuole } \\
\text { surrounded by fibrin }\end{array}$ & $\begin{array}{l}\text { Macrophages, multinucleated giant cells, } \\
\text { lymphocytes, neutrophils, lipid vacuole (clearing) } \\
\text { surrounded by fibrin }\end{array}$ & $\begin{array}{l}\text { Q fever, rarely: leishmaniasis, toxoplasmosis, } \\
\text { cytomegalovirus, typhoid }\end{array}$ \\
\hline
\end{tabular}

the macrophages may show some characteristic morphology (foamy macrophages). Tuberculosis is the most frequent cause of granulomatous inflammation worldwide. Other infectious causes include fungi (histoplasmosis, cryptococcosis, blastomycosis, coccidioidomycosis and some of the molds), parasites (schistosomiasis, leishmaniasis, fasciolosis, enterobiasis), and other bacteria (non-tuberculoid mycobacteria, cat scratch diseases-bartonellosis, tularemia, syphilis, listeriosis, Q fever). Viruses are rarely mentioned as causes of granulomas. Some of the morphologic characteristics tend to be associated with specific organisms and Table 1 presents a correlation between different granuloma morphologies and the usual etiologic agent encountered $[2,4]$.

The correlation of a specific organism with a characteristic granuloma morphology can vary, particularly in immunosuppressed individuals. For example Bartonella henselae can cause cat-scratch disease which is characterized by stellate granulomas but in immunosuppressed patients this bacteria can cause bacillary angiomatosis-peliosis [5]. In HIV infected patients, cutaneous histoplasmosis can have mononuclear and plasma cell inflammatory infiltrate in the superficial and deep dermis with perivascular, perifollicular, and lichenoid patterns and not a granulomatous inflammatory pattern [6]. Although granulomatous inflammation is the usual morphology described for patients with Mycobacterium tuberculosis, there have been some descriptions of cases in which the inflammatory response is not granulomatous. A study of necrotizing nongranulomatous lymphadenitis showed presence of $M$. tuberculosis in 6 out of 35 cases by using molecular methods in formalin-fixed, paraffin-embedded tissues [7].

Granulomas or granulomatous inflammation due to an infectious agent can be associated with other pathologies; thus it may be difficult to recognize it as independently caused entities. The collision of two entities has been documented in HIV patients that have in the same lesion Kaposi sarcoma and granulomas with presence of acid-fast bacilli and molecular evidence of mycobacteria [8]. Patients with breast cancer and tuberculosis in the same lymph node have been described [9].

In some instances there is a granuloma and an infectious agent is found; however, this is not a typical organism that causes granulomas such as Pneumocystis [4, 10]. In these instances the pathologist wonders if other causes should be searched for; however, review of the literature of cases with Pneumocystis and granulomas has not shown presence of other organisms. The variable histopathologic pattern in the presence of the same organism suggests that host factors are at play $[11,12]$. The host factors that have been proposed include presence of CD4 and CD8 lymphocytes, previous Pneumocystis exposure, absence of IgA antibodies against Pneumocystis, and the exposure time to the fungal glycoproteins. The role played by the immune system in formation of granulomas is further emphasized when considering some congenital immunodeficiencies. The typical example is chronic granulomatous disease which is 
a childhood disease involving defects in the phagocytic function as there is reduced nicotinamide adenine dinucleotide phosphate (NADPH) oxidase complex. These patients mount granulomatous inflammation towards most infectious agents and even noninfectious etiologies [13]. Other immune deficiencies such as common variable immune deficiencies can also present granulomatous inflammation towards infectious agents that are not usually associated with granulomas [14].

There are noninfectious causes of granulomas. Foreign bodies such as talc, beryllium, mineral oils, lipids, or medications can produce granulomatous inflammation in diverse organs. Sarcoid-type granulomas are also seen in lymph nodes of patients with lung, stomach or uterine neoplasias [15-17] or may appear in the skin preceding or concomitant with the initial diagnosis of cancer [18]. The presence of granulomatous inflammation may confer better prognosis in some neoplastic diseases as it may indicate some degree of host antitumor activity. This has been documented in patients with small cell carcinoma of the lung in whom there is sarcoid-like granulomatous inflammation of regional draining lymph nodes [19]. Hodgkin's disease is the neoplasia most frequently cited to cause diagnostic confusion because of multisystem granulomatous inflammation which can have various degrees of necrosis [15]. A variety of immune dysfunctions associated with the neoplasia such as a systemic inflammatory reaction with production of chemokines, interleukins and angiogenic factors, immune cellular changes such as anergy, and epigenetic changes such as hyper-methylation have been implicated in the formation of the granulomatous inflammation [18]. Nowadays with the use of immunomodulators such as interferon- $\alpha$ and monoclonal antibodies for different neoplasias and other infections, granulomatous inflammation has been seen after these treatments with no evidence of an infectious agent $[20,21]$.

There are entities that cause granulomas and are specific for certain organs. For example, in the upper respiratory tract Wegener's ganulomatosis, Churg-Strauss syndrome, or cocaine-induced midline destructive lesions [22] need to be considered. In the liver the entities that need to be considered include primary biliary cirrhosis, primary sclerosing cholangitis, hepatitis $\mathrm{C}$, and others $[2,3]$. Also to consider is the variable distribution of granulomas in different tissues in the various entities. For instance, although we think of sarcoid as having most of the lesions in skin, respiratory tract, and lymph nodes [23], 80\% of patients have been shown to have microscopic hepatic granulomas even though symptomatic liver disease is not frequent [24]. From the pathologic perspective we think of Brucella-associated hepatic fibrin ring granulomas; however, these are only seen in 2 to $10 \%$ of cases [2] while vertebral and osteoarticular involvement is probably much more common and the usual causes of mortality include endocarditis and central nervous system involvement $[25,26]$.

The frequency of the different etiologies for the granulomatous inflammation will depend on the prevalence of the diseases in that particular geographical area. For example, a study in Southern Iran of causes of liver granulomas showed that a little over $50 \%$ of their cases were due to tuberculosis and $8 \%$ were due to visceral leishmaniasis while other etiologies included fungal infections, visceral larva migrans, primary biliary cirrhosis, hepatitis $\mathrm{C}$, cytomegalovirus, lymphoma, and others [3]. In this study they used a variety of methods to define the causative agent including histopathology with special stains, PCR, autoantibodies, viral markers, and other characteristics obtained from the chart review which were not always evident at the time the hepatic biopsy was studied. A study in Turkey of hepatic granulomas found that $44 \%$ of their patients had different stages of primary biliary cirrhosis, while only $12 \%$ had tuberculosis (all 10 patients diagnosed with PCR and one having AFB positive staining), $6 \%$ had neoplasias (primarily cancers of hepatic origin), and $4 \%$ had sarcoidosis [27]. An Egyptian study of cutaneous granulomas showed that tuberculosis accounted for $40 \%$ of cases followed by leprosy (32\%), leishmaniasis (16\%), while actinomycetes and fungi were rare [28]. Diagnostic methods for the Egyptian study included intradermal tests, biopsy, serology, direct smear from lesion and PCR.

\section{Mycobacterial Detection Using Molecular Methods in Patients with Granulomatous Inflammation}

Mycobacterial DNA can be recuperated and the species identified using molecular methods in a variety of samples such as sputum, cultures, formalin-fixed, paraffin-embedded tissue blocks that have been used for histopathology, and bones of mummies from Egyptian times [29]. Different primers have been used including: (a) the 123-base pair (bp) segment of the repetitive IS6110 sequence of $M$. tuberculosis complex, which covers $M$. tuberculosis, M. bovis, M. microti, M. africanum, and M. canettii [30-32], (b) EUB338 [33], (c) MTB187 [33], (d) MAVP187 [33], (e) 16S rDNA [34], (f) hsp65 [35], (g) KD1 and KD2 [36], (h) 16SOL-16SOR and 16SIL-16SIR [37], and (i) pncA (Rv2043c) [38]. For the most part, DNA from different specimens is extracted then PCR reactions are performed to detect mycobacteria. Confirmation that the product is $M$. tuberculosis or another mycobacteria has been done by a variety of methods including sequencing and Southern blot. Other methods that have been used to test cultures or formalin-fixed, paraffin-embedded tissue sections are peptide nucleic acid fluorescent in situ hybridization [39], rRNA oligonucleotide probes [33], and spoligotyping (a hybridization step after IS6110 PCR amplification that allows differentiation of the nonrepetitive DNA spacers of $M$. tuberculosis and bovis) [32].

Immunohistochemistry has been used to detect mycobacterial antigens in tissue sections and some authors have found that this technique has better sensitivity than molecular methods in addition to being easier to perform in resource poor settings [40]. However, with immunohistochemistry there is cross-reactivity between the different mycobacteria species [41].

It is important to realize that in many occasions a tissue sample is not sent for cultures since a granuloma or granulomatous inflammation is not found until microscopy is performed and all the tissue, by then, has placed in 
formalin. Also, a sample may have been sent for culture but neither mycobacteria nor fungi grew from the specimen sent to microbiology, thus the only material available for testing is the formalin-fixed, paraffin-embedded tissue. Following we will describe the studies that have focused on studying formalin-fixed, paraffin-embedded material exclusively.

(1) A study of 48 formalin-fixed, paraffin-embedded tissues with granulomas in lung, bone, lymph nodes, liver, genitourinary tract, and other tissues showed positive AFB staining in $8(17 \%)$ cases and molecular evidence of mycobacteria in 19 (40\%) [32]. The authors used the repetitive IS6110 sequence of M. tuberculosis complex to define the presence of mycobacteria and spoligotyping was used to differentiate between the different species. The authors identified $M$. tuberculosis in 7 cases, M. bovis in 4 and in 9 cases the spoligotypic was not able to define the mycobacteria present. Of the cases that were AFB positive, $M$. tuberculosis was found in 5 cases, M. bovis in 1 , and in 2 the determination of the mycobacterial species was not possible.

(2) Another study of 190 cases with granulomas from the respiratory tract, lymph nodes, and other tissues targeted the hsp65 gene in a nested PCR to detect all mycobateria then sequenced or used restriction fraction polymorphisms for species identification [35]. In some cases culture results were available and concordance of molecular and culture results was found in $83 \%$ (34/41 cases). A total of 119 (63\%) cases were positive for mycobacterial DNA. The typical restriction pattern for $M$. tuberculosis complex was present in 71 cases (60\%) while non-tuberculous mycobacteria were found in 41 cases (34\%) and identification was not possible in 15 cases (36\%). Only 7 cases showed AFB positive staining out of 14 that had M. tuberculosis by culture and molecular methods.

(3) In a study from Thailand of 120 skin cases with granulomas in which cultures had been obtained, PCR using 16S rRNA common fragment for mycobacteria and a second $306 \mathrm{bp}$ DNA fragment specific for $M$. tuberculosis was performed [37]. AFB staining in formalin-fixed, paraffin-embedded sections showed positivity in $31 \%$, by PCR $36 \%$ were positive and by culture $30 \%$. There were 12 cases that were positive with both AFB stains and PCR, 21 that were AFB positive but PCR negative, and 35 that were PCR positive but AFB negative. The sensitivity and specificity of PCR against AFB results was 29 and 61\%, respectively, and when compared to culture these were 67 and $76 \%$. The low number of cases with positive results for PCR was attributed to inhibitors present in the tissues.

(4) A study from Hong Kong of 115 patients correlated histopathology, culture and PCR results [30]. The authors used the IS6110 target and confirmation of $M$. tuberculosis was performed by Southern blot hybridization. Between 1 to 3 paraffin blocks per patient were tested as they assumed that mycobacteria were scant and randomly distributed in the tissues. They looked at granulomatous inflammation of 62 pulmonary specimens and 53 extrapulmonary sites. Only 68 patients had PCR and culture results. The authors showed that 20 patients were positive using culture and PCR, 2 were PCR negative but culture positive, and 13 were negative for culture and PCR. An additional 35 cases were positive with PCR but no cultures were available for them. Positive AFB staining and PCR occurred in 12 cases.

(5) A study from Korea looked at 250 patients with culture and AFB smears that required lung biopsies because the clinical diagnosis of tuberculosis was uncertain [31]. In this study the authors calculated sensitivity and specificity of nested PCR using the IS6110 target against culture to be 85 and 99\%, respectively.

(6) A study of 50 Indian patients with abdominal tuberculosis showed 31 cases positive with histopathology and 30 with a PCR that used the KD1 and KD2 target [36]. Only 24 cases were concomitantly positive with histopathology and PCR and 11 that were negative with both techniques. In 4 patients the PCR did not yield results due to inhibitors.

(7) A study of 12 Japanese patients with granulomatous inflammation of musculoskeletal tissues used the $16 \mathrm{~S}$ rDNA and sequenced the products of the formalinfixed, paraffin-embedded tissues [34]. They obtained amplicons from 5 cases $(41 \%)$ and the mycobacteria found included M. tuberculosis in 4 cases and $M$. avium in one. Four of these cases showed AFB in the tissues, 3 cases had M. tuberculosis and one M. avium.

(8) A second group from Korea correlated histopathology, AFB staining and a nested PCR using the repetitive IS6110 sequence of $M$. tuberculosis complex in 81 patients [42]. They studied a variety of tissues from the respiratory tract, lymph nodes, gastrointestinal tract, soft tissues, and others. They had 53 cases with granulomatous inflammation in which 17 were AFB positive and $36 \mathrm{PCR}$ positive. Of the $17 \mathrm{AFB}$ positive cases 14 were also PCR positive thus 3 cases were attributed to other mycobacteria. Of the 28 cases with chronic inflammation but no definitive evidence of granulomas none showed positive AFB while 10 showed evidence of $M$. tuberculosis by PCR.

(9) A study from Spain of 10 patients with papulonecrotic tuberculid skin lesions demonstrated that 8 had M. tuberculosis complex in formalin-fixed, paraffinembedded skin biopsies [43]. The authors used a 285bp sequence specific of $M$. tuberculosis complex that was confirmed by Southern blot hybridization. In this study the patients did not have respiratory evidence of tuberculosis but all were PPD positive.

Although these studies have used an array of different clinical presentations, tissues, and pathologies, they have 
established that PCR can detect mycobacteria in 36 to $60 \%$ of formalin-fixed, paraffin-embedded specimens. In many instances staining AFB in the tissue was not observed. If the primer used in the study was specific for M. tuberculosis, presence of AFB staining did not correlate with PCR positivity and in those cases the authors commented that the AFB could correspond to other mycobacteria. From the previous studies that used formalin-fixed, paraffin-embedded tissues and others that have used a variety of materials such as fresh samples and cultures it is clear that obtaining a product for PCR analysis using a broad mycobacterial target then sequencing and comparing with known GenBank sequences can reveal that those mycobacteria are not $M$. tuberculosis but other mycobacteria. Examples of detection of these mycobacteria are presented in Table 2.

Detection of mycobacterial species does not seem to improve if fresh tissues rather than formalin-fixed, paraffinembedded tissues are used. A study from India that used fresh tissue to perform PCR for M. tuberculosis targeting the IS6110 gene and compared to histopathology (necrotizing granulomas) showed that 20 of 104 (19\%) samples were both positive with AFB and PCR while 74 (71\%) were negative for both [44]. Discrepant results occurred in 7 cases, 4 of these were positive with the AFB stain but negative with PCR and 3 were positive with PCR but negative with AFB.

Molecular techniques are expected to increase sensitivity and specificity; however, in some instances this does not occur. A study of bovine lymph nodes with Mycobacterium bovis used the IS1081 which detects down to 1 genome copy and the RD4 which detects 5 genome copies. The authors determined a sensitivity of $70 \%$ and $50 \%$, respectively, for each probe compared to culture [45]. When analyzing why the recovery with PCR was lower than expected, the authors determined that there was limited recovery of mycobacterial DNA which may have been due to the resilient mycobacterial cell wall, the presence of tissue debris and the paucibacillary nature of some of the lesions. In order to decrease the amount of tissue debris researchers have compared PCR on laser capture microdissection material to the entire formalin-fixed, paraffin-embedded tissue sections but found no improvement in sensitivity and specificity for detection of M. tuberculosis [46].

In some instances the organism detected by the molecular technique may not be the same obtained in cultures. A study of resected lung specimens from 24 patients with nontuberculous mycobacterial disease correlated the organisms identified by culture of tissue or sputum to the results obtained from molecular testing using IS6110 to detect $M$. tuberculosis and hsp65 gene which was later sequenced [47]. In 12 patients the culture and sequencing analysis rendered the same organism. In 8 patients the culture and PCR results were discrepant. In 6 of the patients the culture showed a rapid grower. Ten of the patients had fibrocavitary disease and in all but 2 more than one mycobacteria were identified. The authors suggested that the frequent discrepancies between the PCR and culture results were possibly due to multiple non-tubercoulus bacteria colonizing the lesions. The authors comment that when using PCR, the most abundant mycobacteria is the one identified although in some instances more than one mycobacteria were observed. In contrast, the organism that overtakes the culture is the one growing faster.

By use of molecular techniques new species of mycobacteria are being discovered. For example, a case of skin papules and nodules that showed granulomatous inflammation in a patient with Hodgkin's disease and severe cellular immunodeficiency demonstrated Mycobacterium simiae when using the sequence of the product of 16S rRNA. However, based on culture characteristics, susceptibility testing, molecular testing targeting different portions of the mycobacteria gene ( $r p o B$ and $h s p 65$ ), and high-performance liquid chromatography of mycolic acid methyl esters the mycobacteria was determined to be a novel one and the authors proposed this to be called $M$. shigaense [48].

Molecular testing has also been useful in study of nosocomial infections as it can define the species of mycobacteria and other mutations that can occur. For example, random amplified polymorphic DNA-PCR was used to define clonicity of Mycobacterium abscessus in isolates from 8 patients that had granulomatous prostatitis after biopsies had been performed on them [49]. All isolates were indistinguishable from one and other suggesting that all isolates came from the same clone and had been nosocomially acquired.

\section{Detection of Organisms Other than Mycobacteria Using Molecular Methods in Patients with Granulomatous Inflammation}

Our currently used culture and staining techniques are optimized to identify microbial agents that are known to cause disease. Similarly, detection of antigens, antibodies, or presence of nucleic acids are targeted to identify a particular suspect disease. Table 3 presents methods that can be used for diagnosis of infectious agents not related to mycobacteria that cause granulomatous inflammation.

To discover new pathogens, molecular methods that use conserved portions of microbial genomes to obtain products which are then sequenced are ideally suited for this task. For bacteria and fungi, some portions of the ribosomal nucleic acids are highly conserved and can be used to determine the genus and species. Tropheryma whippelii is a clear example of discovering an agent for a disease that had long been thought to be infectious but in which cultures had failed to give us the microbial agent [97]. The discovery was based on obtaining a product using a $16 \mathrm{~S}$ ribosomal RNA (rRNA) primer and then sequencing the product. Sequencing the $16 \mathrm{~S}$ rRNA product of bacillary angiomatosis lesions demonstrated that $B$. henselae (previously Bartonella bacilliformis) was the causative agent [98]. In the case of T. whippelii the genetic sequence was not recognized thus this was a new distinct bacterium while comparing the sequence of $B$. henselae to others published at the time demonstrated that the bacteria present in bacillary angiomatosis lesions was related to Bartonella and Rochalimaea. As described previously, this conserved nucleic acid sequence of bacterial small rRNA has been used for detection of different mycobacteria species. In the case of fungi, products of conserved rRNA genes (18S, $28 \mathrm{~S}$ and 5.8S) or the intervening internal transcribed spacer 


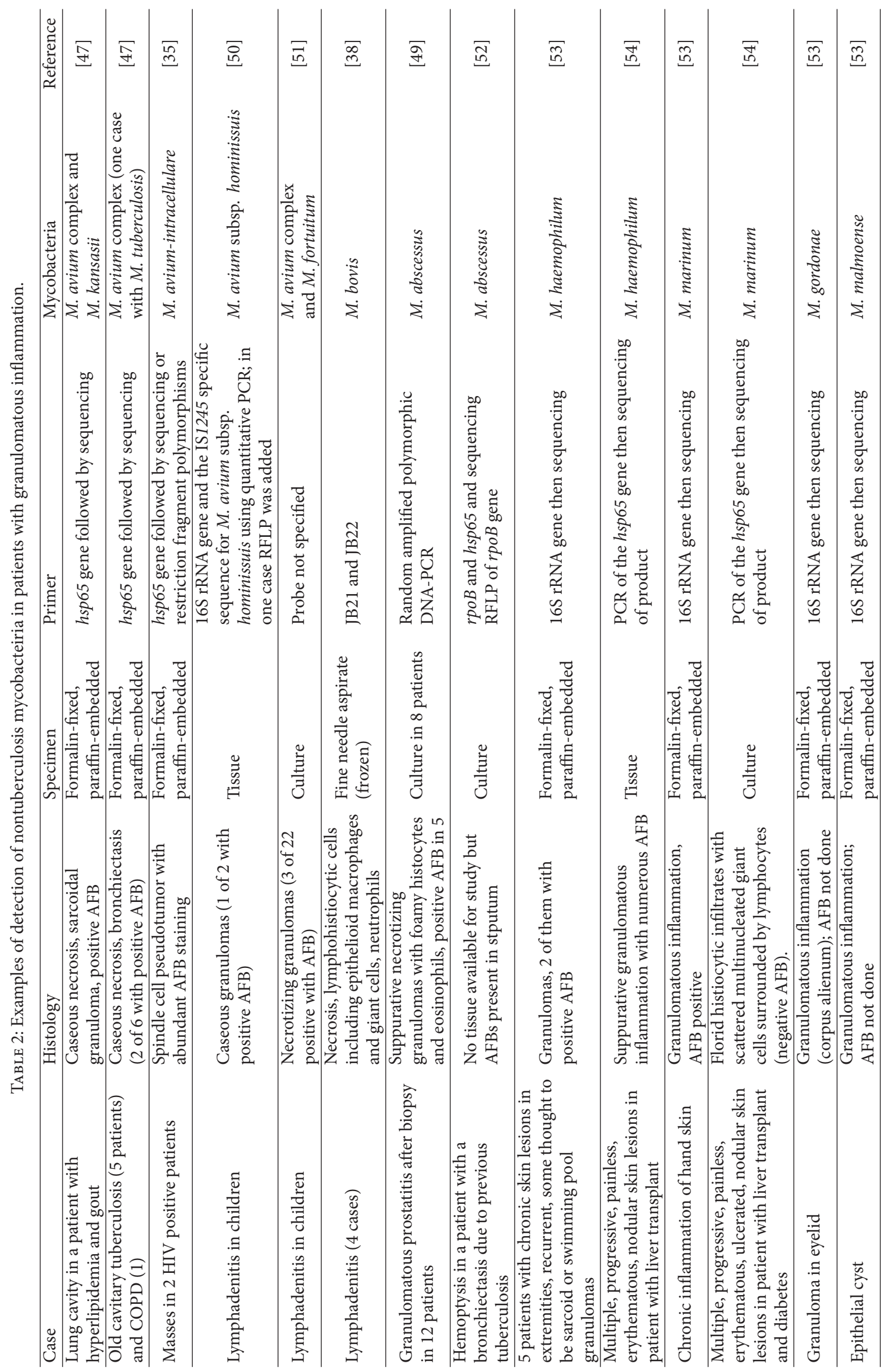




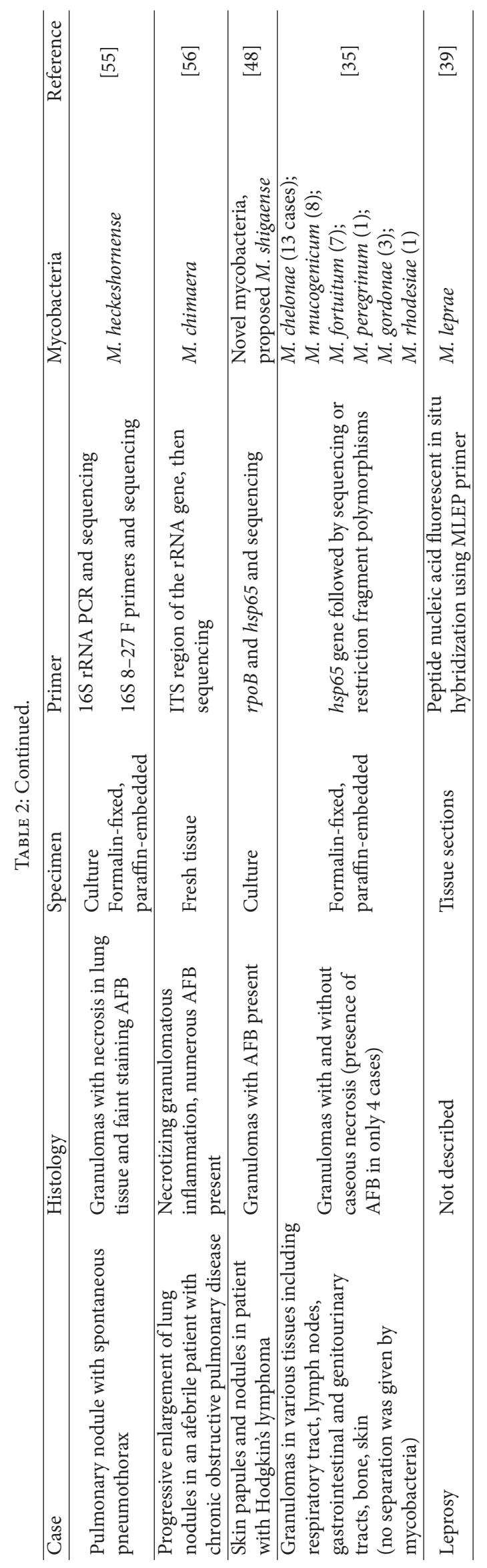


TABLE 3: Methods that have been used to define nonmycobacterial infectious agents that can cause granulomatous inflammation.

\begin{tabular}{|c|c|c|c|c|c|}
\hline Disease & PCR & Serology & Culture & $\begin{array}{l}\text { Visualization of } \\
\text { organism in histology } \\
\text { or other }\end{array}$ & Ref. \\
\hline $\begin{array}{l}\text { Bartonella } \\
\text { henselae }\end{array}$ & $\begin{array}{l}\text { From lesion, } 12 \text { of } 14 \\
(86 \%) \text {; in another series } \\
\text { that studied } 33 \\
\text { granulomatous } \\
\text { lymphadenitis } 7 \text { cases } \\
\text { positive. }\end{array}$ & 23 of 23 positive. & $\begin{array}{l}\text { Recovery in cultures } \\
\text { approaches } 50 \% .\end{array}$ & $\begin{array}{l}\text { Requires bacterial } \\
\text { silver staining for } \\
\text { visualization, was } \\
\text { detected in } 12 \text { of } 19 \\
(63 \%) .\end{array}$ & {$[5,51]$} \\
\hline Brucella & $\begin{array}{l}\text { From bone marrow } \\
\text { aspirates, serum and } \\
\text { blood. Can be used after } \\
\text { antibiotics have been } \\
\text { given. }\end{array}$ & $\begin{array}{l}\text { Several methods with } \\
\text { varying sensitivity } \\
\text { (agglutination, ELISA). }\end{array}$ & $\begin{array}{l}\text { Sensitivity depends on } \\
\text { stage of disease and sample } \\
\text { type, requires extended } \\
\text { culture time as the bacteria } \\
\text { grows slowly. Laboratory } \\
\text { acquired cases can occur, } \\
\text { careful handling is needed. }\end{array}$ & $\begin{array}{l}\text { Requires IHC or } \\
\text { immune-fluorescence } \\
\text { for visualization. }\end{array}$ & {$[26,57]$} \\
\hline Tularemia & $\begin{array}{l}\text { RT-PCR from blood and } \\
\text { tissues in } 39 \% \text { of } 101 \\
\text { patients. } 14 \text { of } 15 \text { cases } \\
\text { in tissues. }\end{array}$ & $\begin{array}{l}\text { Microagglutination, } \\
\text { immunofluorescence for } \\
\text { detection of IgG and IgM } \\
\text { in } 94 \% \text { of } 101 \text { patients. }\end{array}$ & $\begin{array}{l}\text { Culture in } 21 \% \text { of } 101 \\
\text { patients. }\end{array}$ & $\begin{array}{l}\text { Requires bacterial } \\
\text { silver staining or IHC } \\
\text { for visualization }\end{array}$ & {$[58,59]$} \\
\hline $\begin{array}{l}\text { Yersinia } \\
\text { enterocolitica }\end{array}$ & Not done. & ELISA testing is not useful. & $\begin{array}{l}\text { Most cases diagnosed this } \\
\text { manner. MALDI-FOF has } \\
\text { been used for specific } \\
\text { identification. }\end{array}$ & Not commented. & $\begin{array}{c}{[51,60,} \\
61]\end{array}$ \\
\hline Syphilis & $\begin{array}{l}\text { PCR } 39 \text { to } 69 \% \text { of } \\
\text { biopsies. }\end{array}$ & Varies depending on stage. & Not available. & $\begin{array}{l}\text { Requires bacterial } \\
\text { silver stain (Dieterle or } \\
\text { Steiner) for } \\
\text { visualization }(25 \%) \text {; } \\
\text { increases sensitivity } \\
\text { with IHC ( } 49 \text { to } 51 \%) \text {. }\end{array}$ & {$[62,63]$} \\
\hline Leishmania & $\begin{array}{l}\text { Used for detection and } \\
\text { defining species, in } \\
\text { meta-analysis very high } \\
\text { diagnostic odds ratio. } \\
\text { Using skin } \\
\text { formalin-fixed, } \\
\text { paraffin-embedded } \\
\text { samples detection rate is } \\
97 \% \text {. }\end{array}$ & $\begin{array}{l}\text { Limited sensitivity which } \\
\text { depends on assay used, } \\
\text { type of disease (cuteanous } \\
\text { versus visceral). }\end{array}$ & $\begin{array}{l}\text { Can be done but not } \\
\text { routine with } 58 \% \\
\text { sensitivity. }\end{array}$ & $\begin{array}{l}\text { Visualization with } \\
\text { H\&E, but when } \\
\text { numbers of parasites } \\
\text { are low, they may be } \\
\text { difficult to diagnose. } \\
\text { Enhanced with IHC to } \\
88 \% \text { sensitivity. }\end{array}$ & $\begin{array}{c}{[64-} \\
67]\end{array}$ \\
\hline Toxoplasma & $\begin{array}{l}\text { Can be performed in } \\
\text { tissues and blood, } \\
\text { different primers, good } \\
\text { for diagnosis of } \\
\text { congenital disease. }\end{array}$ & $\begin{array}{l}\text { Variety of assays available. } \\
\text { IgG indicates past } \\
\text { infection, IgM can remain } \\
\text { increased up to } 2 \text { years } \\
\text { after acute infection. }\end{array}$ & $\begin{array}{l}\text { By inoculating mice (in } \\
\text { reference laboratories). }\end{array}$ & $\begin{array}{l}\text { Visualization with } \mathrm{H} \& \mathrm{E} \\
\text { in placenta and other } \\
\text { tissues. Enhanced with } \\
\text { IHC. }\end{array}$ & $\begin{array}{c}{[68-} \\
70]\end{array}$ \\
\hline Acanthamoeba & $\begin{array}{l}\text { Can reach } 89 \% \\
\text { sensitivity in specimens } \\
\text { from patients with } \\
\text { keratitis. Cyst formation } \\
\text { decreases sensitivity. } \\
\text { Species can be defined } \\
\text { using PCR. }\end{array}$ & Not available. & $\begin{array}{l}\text { Is done primarily for } \\
\text { diagnosis of keratitis using } \\
\text { a lawn of Escherichia coli. }\end{array}$ & $\begin{array}{l}\text { Amoeba are visualized } \\
\text { with H\&E in patients } \\
\text { with granulomatous } \\
\text { meningo encephalitis } \\
\text { or keratitis; enhanced } \\
\text { diagnosis by use of } \\
\text { immune assays (DFA } \\
\text { or IHC). }\end{array}$ & $\begin{array}{c}{[71-} \\
74]\end{array}$ \\
\hline Schistosoma & $\begin{array}{l}\text { PCR in urine can have } \\
\text { up to } 100 \% \text { sensitivity } \\
\text { and } 91 \% \text { specificity. }\end{array}$ & $\begin{array}{l}\text { Detection of antibodies: } \\
\text { may cross-react with other } \\
\text { helminth infections, IgM } \\
\text { may persist long after acute } \\
\text { infection. Detection of } \\
\text { antigen: in urine and } \\
\text { serum. Sensitivity ranges } \\
\text { from } 41-78 \% \text { and } \\
\text { specificity between } \\
76-100 \% \text {. }\end{array}$ & Not available. & $\begin{array}{l}\text { Detection of ova in } \\
\text { stool or urine; } \\
\text { quantification in a fixed } \\
\text { amount of urine or } \\
\text { stool allows to } \\
\text { determine intensity of } \\
\text { infestation. Adult } \\
\text { worms and eggs can be } \\
\text { seen in tissue sections. }\end{array}$ & $\begin{array}{c}{[75-} \\
78]\end{array}$ \\
\hline
\end{tabular}


TABLE 3: Continued.

\begin{tabular}{|c|c|c|c|c|c|}
\hline Disease & PCR & Serology & Culture & $\begin{array}{l}\text { Visualization of } \\
\text { organism in histology } \\
\text { or other }\end{array}$ & Ref. \\
\hline Fasciola & $\begin{array}{l}\text { PCR from stools and } \\
\text { eggs from adult worms } \\
\text { obtained from humans } \\
\text { and animals. }\end{array}$ & $\begin{array}{l}\text { By ELISA the sensitivity is } \\
95 \% \text { and specificity } 95 \% \text {. } \\
\text { No correlation with } \\
\text { number of ova in stool. }\end{array}$ & Not available. & $\begin{array}{l}\text { Detection of ova in } \\
\text { stool. Adult worms and } \\
\text { eggs can be seen in } \\
\text { tissue sections. }\end{array}$ & $\begin{array}{c}{[79-} \\
81]\end{array}$ \\
\hline Anisakis & $\begin{array}{l}\text { Case detected by PCR } \\
\text { from ileocecal } \\
\text { formalin-fixed, } \\
\text { paraffin-embedded } \\
\text { tissue. }\end{array}$ & $\begin{array}{l}\text { Seroprevalence using IgE } \\
\text { ELISA has been } \\
\text { documented to be } 6 \% \text { in } \\
\text { Korea. }\end{array}$ & Not available. & Visualized with H\&E. & {$[82,83]$} \\
\hline $\begin{array}{l}\text { Pneumocystis } \\
\text { jirovecii }\end{array}$ & $\begin{array}{l}\text { PCR has been used in } \\
\text { bronchioalveolar lavage } \\
\text { for diagnosis and to } \\
\text { define colonization in } \\
\text { transplant patients. Can } \\
\text { be used for genotyping. }\end{array}$ & $\begin{array}{l}(1 \rightarrow 3) \beta \text {-D-glucan has a } \\
\text { diagnostic sensitivity of } \\
95 \% \text { but specificity is } 86 \% \\
\text { since there is } \\
\text { cross-reactivity with other } \\
\text { fungal infections. }\end{array}$ & Not available. & $\begin{array}{l}\text { Visualized with H\&E or } \\
\text { fungal silver stain. } \\
\text { Fluorescent antibodies } \\
\text { can be used. }\end{array}$ & $\begin{array}{c}{[12,} \\
84-87]\end{array}$ \\
\hline Histoplasma & $\begin{array}{l}\text { Sensitivity of PCR on } \\
\text { formalin-fixed, } \\
\text { paraffin-embedded } \\
\text { tissues } 89 \% \text {. From fresh } \\
\text { specimens sensitivity is } \\
100 \% \text { and specificity } \\
73 \% \text {. }\end{array}$ & $\begin{array}{l}\text { Urine and serum antigen } \\
\text { cross-react with } \\
\text { Blastomyces. Antibodies } \\
\text { can also be measured. }\end{array}$ & $\begin{array}{l}\text { Can take up to } 4 \text { weeks to } \\
\text { grow. Can be found in } \\
\text { blood cultures. }\end{array}$ & $\begin{array}{l}\text { Visualized with H\&E, } \\
\text { PAS and fungal silver } \\
\text { stain (these are small } \\
\text { yeasts with narrow } \\
\text { based budding). }\end{array}$ & $\begin{array}{c}{[84,88,} \\
89]\end{array}$ \\
\hline Blastomyces & $\begin{array}{l}\text { From fresh specimens } \\
\text { sensitivity is } 99 \% \text { and } \\
\text { specificity } 86 \% \text {. }\end{array}$ & $\begin{array}{l}\text { Urine and serum antigen } \\
\text { cross-react with } \\
\text { Histoplasma. Antibodies } \\
\text { can also be measured. }\end{array}$ & $\begin{array}{l}\text { Grows well but may take } \\
\text { several weeks. }\end{array}$ & $\begin{array}{l}\text { Visualized with H\&E, } \\
\text { PAS and fungal silver } \\
\text { stain (these are } 6-15 \\
\text { micron yeasts with } \\
\text { broad based budding). }\end{array}$ & $\begin{array}{l}{[84,89,} \\
90]\end{array}$ \\
\hline Coccidioides & $\begin{array}{l}\text { PCR on fresh respiratory } \\
\text { specimens has a } \\
\text { sensitivity of } 75 \text { and } \\
\text { specificity of } 99 \% .\end{array}$ & $\begin{array}{l}\text { Antibodies can be } \\
\text { measured using several } \\
\text { methods. IgG response can } \\
\text { be abrogated if treatment is } \\
\text { started early. }\end{array}$ & $\begin{array}{l}\text { Grows within } 2 \text { to } 3 \text { weeks. } \\
\text { It is a select agent and it } \\
\text { needs to be handled with } \\
\text { care due to potential } \\
\text { laboratory transmission. }\end{array}$ & $\begin{array}{l}\text { Visualized with H\&E, } \\
\text { PAS and fungal silver } \\
\text { stain (diagnostic } \\
\text { structures are spherules } \\
\text { with endospores; } \\
\text { endospores on their } \\
\text { own can be confused } \\
\text { with Blastomyces and } \\
\text { other yeasts). }\end{array}$ & $\begin{array}{c}{[84,} \\
91-93]\end{array}$ \\
\hline Paracoccidioides & $\begin{array}{l}\text { PCR has been performed } \\
\text { in tissues, including fine } \\
\text { needle aspirates. There } \\
\text { are commercial kits } \\
\text { available. }\end{array}$ & $\begin{array}{l}\text { Several methods available, } \\
\text { including Western blots. } \\
\text { Some have important } \\
\text { cross-reactivity with other } \\
\text { yeasts, particularly } \\
\text { Histoplasma. }\end{array}$ & $\begin{array}{l}\text { Growth may take up to } 2 \\
\text { months. }\end{array}$ & $\begin{array}{l}\text { Visualized with H\&E, } \\
\text { PAS and fungal silver } \\
\text { stain (yeasts with } \\
\text { multiple-more than } 3 \\
\text { buds, mariner's wheel, } \\
\text { are diagnostic). }\end{array}$ & $\begin{array}{c}{[84,} \\
94-96]\end{array}$ \\
\hline
\end{tabular}

IHC: immunohistochemistry, H\&E: hematoxylin and eosin, DFA: direct fluorescent antibody, PAS: periodic acid shift stain.

(ITS1 and ITS2) regions can be obtained, sequenced and the latter compared to what has been published to help determine the fungal genus and species present in the tissue $[84,99,100]$. A retrospective study of fungi in formalin-fixed, paraffinembedded tissues using conserved primers and sequencing the product obtained showed that nucleic acid recovery varied from 60 to $90 \%$ depending on the method used for extraction and led to a PCR efficiency of 57 and $93 \%$ which translated to approximately $60 \%$ recovery of the fungi to the genus level [101]. For parasites and viruses, widely conserved regions are not available.
Even with these advances, we are constantly confronted with cases in which an infectious agent is suspected but no specific agent can be found. A typical entity falling in this category is sarcoidosis which has always been suspected to be of infectious origin but in which finding the causative organism has been elusive [23]. These patients have granulomas with little necrosis and no mycobacteria or fungi are observed in the tissue by using conventional techniques or evidence of a microorganism is found by a variety of methods (culture, skin testing) at the time of original diagnosis. New molecular methods and immunologic assays 
have been used to study a variety of sarcoidosis samples and the association with a variety of mycobacteria appears to be strong [23, 102]. Using Mycobacterium species $16 \mathrm{~S}$ rRNA and $r p o B$ sequences, researchers have found that $60 \%$ of lung biopsies and lymph nodes pathologically classified as sarcoid contained mycobacteria; however, the IS6110 specific for $M$. tuberculosis was negative [103]. This study found a heterogeneous group of mycobateria that are closely related to $M$. tuberculosis, M. gordonae, and M. kansasii. The amount of mycobacteria using real-time quantitative PCR targeting the IS986 of the M. tuberculosis genome in formalin-fixed, paraffin-embedded specimens of patients with sarcoidosis is present in low numbers compared to controls [104]. Moreover, IgG antibodies against $M$. tuberculosis catalaseperoxidase have been found in a high proportion of patients with sarcoidosis compared to controls [105].

In addition to mycobateria, other organisms including Propionibacterium acnes have been found in greater amount in specimens from patients with sarcoidosis by molecular analysis too $[23,106]$. The literature that links mycobacteria with sarcoidosis has primarily been observed in American subjects while that linking Propionibacterium with sarcoidosis is in Japanese persons, suggesting that host genetics play an important factor regarding the possible causative agent to what we now call sarcoidosis. Even when organisms, in particular mycobacteria, are isolated or found in patients in whom a previous diagnosis of sarcoidosis had been given, the question of whether the mycobacteria was the cause of the granulomas or if there are concomitant diseases (sarcoidosis and an infection with a mycobacteria) is always present [102].

Nowadays a revolution in microbiology laboratories is taking place with the use of matrix-assisted laser desorption/ionization time-of-flight (MALDI-TOF) mass spectrometry analysis $[107,108]$. This method studies the composition of biomolecules in bacteria including proteins, DNA, sugars and others. The fingerprint of a growing number of bacteria are now in the libraries of MALDI-TOF mass spectrometers. For this method, bacterial colonies are placed in a matrix and allowed to cocrystallize with the matrix as it dries. Then the sample is fired with a laser causing ionization of the biomolecules. The ionized particles are pulsed into a time-of-flight mass spectrometer. Timeof-flight mass spectrometers have a "mirror" that reflects the ions and allows for better discrimination between the biomolecules measured creating a fingerprint pattern specific for the bacteria. Then the pattern of the suspect organism is compared to a library of patterns and identification to the genus and species level can be achieved based on the specific fingerprint of biomolecules. For some organisms the discrimination of the fingerprint has a success that ranges between 89 to $100 \%$ for the genus and between 84 to $95 \%$ for the species. Since identification is based on the organisms available in the library, as a wider diversity of organisms are entered into the libraries of the different instruments in the market identification rate will improve. At this point, the instrumentation is expensive; however, the identification of each sample is cheap. Bacterial identification is much faster once a pure colony has been isolated since bacterial growth with production of a variety of biochemical reactions is not needed which will be a major improvement in turnaround time for identification of mycobacteria. It should be noted that for some organisms an extraction phase is necessary. Study of primary specimens using MALDI-TOF is being pursued for sterile sites such as blood, cerebrospinal fluid, and fine needle aspirates which may allow discovery of microbiologic agents that are fastidious growers and cause granulomatous inflammation.

Lastly, there may be some granulomatous inflammatory processes in which a causative agent may never be found and some authors have suggested that host factors play a mayor role. A Canadian study of central nervous system granulomas with caseous necrosis but in which an etiologic agent could not be determined, demonstrated no improvement or worsening of clinical and radiologic features after treating with antimycobacterial regiments but improvement after immunomodulation therapy with prednisone or azathioprine [109]. In this study, search for causative agents, primarily mycobacteria, included a variety of stains, cultures, and PCR and the authors suggested that if no organism is found the most probable cause is not infectious but a variant of a hypersensitivity reaction, possibly sarcoidosis, where granulomas show necrosis.

\section{Formation and Function of Granulomas}

Traditionally granuloma formation has been thought as an adaptive cellular immune process. There are several phases in the formation of granulomas: initiation, accumulation, effector, and resolution [24]. Initiation takes place when an antigen is presented by a macrophage or dendritic cell to CD4 lymphocytes. The presentation is usually done through use of Toll-like receptors that recognize a variety of structural components such as mycolic acids and peptidoglycans present in the cell wall of mycobacteria and other granuloma inducing agents [110]. T helper 1 (Th1) CD4 cells are usually involved in mycobacterial diseases and sarcoidosis, while $\mathrm{T}$ helper 2 (Th2) CD4 cells are usually involved when there is a parasitic infection. As infection progresses, there can be switching from Th1 to Th2 cell response. Th1 cells produce Il-2 and interferon $\gamma$ (IFN $\gamma$ ) which recruit more CD4 cells and macrophages and are indispensible for the accumulation phase [110]. Other chemokines that play a role include tumor necrosis factor (TNF), and several interleukins produced by Th2 cells (IL-4, IL-5, and IL-13) and macrophages (IL-12). The Th1 response induced delayed hypersensitivity reactions while the Th2 response stimulates antibody production, in particular IgE [111]. The new milieu recruits CD8 lymphocytes and neutrophils and is important for the effector phase. Lastly the resolution phase includes the deposition of collagen and creation of fibrosis. This conventional thought regarding the formation of granulomas results in walling off the noxious agent.

Recent experiments have challenged some of the concepts regarding the production of granulomas. Following we will explore how our understanding of different components has evolved with respect to granulomas formed by different agents. Neutrophils in granulomatous inflammation have an 
active role [112]. Experiments using intradermal injections of Bacille Calmette-Guerin (BCG) have shown that neutrophils, rather than macrophages, are the cells that carry the mycobacteria into the lymph nodes. Once in the lymph nodes, neutrophils present mycobacterial antigens to dendritic cells that then recruit CD4 cells and lead to production of IFN $\gamma$. In addition, neutrophilic proteins are present in macrophages located in ganulomatous inflammation. It is postulated that these proteins serve to enhance phagocytic properties of macrophages. Although the important role of neutrophils is histopathologically confirmed in Bartonella, Listeria, Candida, and Toxoplasma granulomatous inflammation [58], neutrophils have not been traditionally considered an important component in mycobacterial infections.

Other researchers have demonstrated that innate immunity is an important component of granulomatous inflammation. Using zebrafish larvae which do not have adaptive immunity, researchers have shown that granulomas form when they are exposed to Mycobacterium marinum [1]. The zebrafish experiments have also demonstrated that macrophages that have ingested the infectious agent during early infection are responsible of propagating the infection to other macrophages as they undergo apoptosis rather than containing the infectious agent [113]. Macrophages forming granulomas move rapidly towards infected macrophages and ingest mycobacteria. This exchange usually occurs at the periphery of the granuloma. The signal for macrophage movement is derived from the pathogen and the dying infected macrophage. As the newly recruited macrophage ingests the contents of the dying one, it allows for mycobacteria to multiply and disperse with the moving macrophage. In this manner, the infection is not walled off but disseminated from a primary site to a secondary one. In addition to macrophages moving fast through the granuloma, $\mathrm{T}$ cells are also moving. Thus, it is postulated that there are 2 types of functional granulomas: those with rapid moving macrophages which are formed in response to infectious agents such as mycobacteria and those with slow moving macrophages which include those responding to foreign bodies [1].

Review of histopathologic descriptions of tuberculosis in the preantibiotic era comment that primary infection resulted in an exudative reaction which included foamy alveolar macrophages and some degree of lipid necrosis and systemic dissemination of the mycobacteria [114]. Using molecular techniques, some investigators have corroborated that mycobateria are disseminated through the body by using PCR and spoligotyping [115]. The mycobacteria have been found during latent infection in vertebrae $[29,116]$, spleen, kidney and liver [115]. By using in situ hybridization, the mycobacteria have not only been present in macrophages, but also in endothelial cells of these organs [115]. Of interest is that in the same patient more than one bacterial genotype was found.

Our understanding of the role that different mediators have has also evolved through time. For example, it appears that TNF is not indispensable for the formation of granulomas due to mycobacteria in zebrafish. However, the role of matrix metalloproteinase 9 (MMP9) secreted by epithelial cells is very important for recruiting macrophages and forming granulomas [117]. MMP9-knockout mice that have been infected with $M$. tuberculosis have poor granuloma formation and low amounts of mycobacteria.

Besides the host factors discussed, there are new discoveries that involve mycobacterial factors. For example, it is now recognized that there are several cell wall lipids that arrest the maturation of phagosomes and do not allow acidification [118]. The shift from an external $\mathrm{pH}$ of 7 to the phagosomal $\mathrm{pH}$ of 6.4 shapes the transcriptional response of mycobacteria allowing them to continue to grow inside the macrophage by using host cholesterol and other cell lipids as nutritional sources. In addition, mycobacteria avoid destruction by superoxide by using superoxide dismutase and by cell wall lipidoglycans scavenging the oxygen radicals. The mycobacteria residing inside the phagosomes release proteins and lipids that traffic actively through the infected cell. As a pathologist one would expect abundance of bacilli in these lesions but the organisms are usually difficult to find. One explanation to pathologist's inability to find mycobacteria may be due to an incompletely formed cell wall during the replicative process which does not allow visualization with the techniques we currently use. Some researchers have studied the lipid composition of the caseous necrosis in tuberculoid granulomas and have found that there is dysregulation of lipid metabolism in macrophages with disproportionate abundance of certain lipid metabolic pathways [119] which explains why there is a lot more caseum than bacteria in them. Another possible explanation is that mycobacteria become cell wall deficient due to the host immune response and the shape and acid-fast staining of the mycobacteria is atypical or lacking $[120,121]$.

Microscopically, acid-fast bacilli are usually found in the interface between necrotic cellular debris and areas with caseous necrosis. As the granuloma becomes older, bacteria become sparser in the areas of hard necrosis. Review of histopathologic descriptions of tuberculosis in the preantibiotic era comment that post primary tuberculosis lesions start with foamy macrophages that have ingested the organisms [114]. In $90 \%$ of the cases the lesions regress spontaneously and fibrosis is noted in the area where the foamy macrophages were, but in $10 \%$ of the cases the lesions evolve to caseous necrosis and cavity formation. The numbers of acid-fast bacilli in these cavities are increased and as the individual coughs, other persons are at risk of acquiring the disease.

A similar distribution of mycobacteria has been found in granulomas of immune competent patients caused by Mycobacterium avium complex [122]. During initial infection, when only one exudative lesion is seen, there are many organisms inside mononuclear cells. As the lesions progress to a well defined granuloma with necrosis, there are less organisms which are usually present in the periphery either inside mononuclear cells or in the necrotic material.

Schistosoma produced granulomas in humans show a mixed Th1-Th2 response that will vary depending on the genetic background of the host, nutritional status, intensity and duration of the infection, and concurrent pathology [111]. In murine animal models the Th2 response with a large population of eosinophils dominates the response to 
schistosome eggs. The Th2 response with production of IL10 and IL-13 favors fibrosis but, this response may also depend on other compounds such as nitric oxide synthase. The Th1 response with production of TNF, IFN $\gamma$ and IL12 is responsible for antifibrotic activity [111, 123]. Also in play is an increase in Treg cells that modulate the Th1-Th2 response. In immunocompetent hosts, Schistosoma eggs elicit a collagen-rich granulomatous response to try to sequester egg products, but this same response can lead to extensive hepatic fibrosis. Understanding the pathobiology of this parasitic infection gives us insights into the difficulties that can occur when in a liver biopsy, granulomas with eosinophils and extensive fibrosis are found but no egg parasite can be identified. To further define what is causing the disease in each individual patient requires epidemiologic information that will guide further serologic, molecular and other studies. Studies of formation of granulomas in vitro using peripheral blood cells from patients with acute and chronic $\mathrm{Q}$ fever and healthy controls have corroborated some of the findings from the zebrafish and shed some insights into differences encountered at various stages of the disease [124]. In their experiments, monocytes from healthy donors were the ones that initiated granuloma formation but well formed granulomas required the presence of $\mathrm{T}$ lymphocytes. In addition to monocytes and lymphocytes, their granulomas had epithelioid macrophages, and multinucleated giant cells, but no dendritic cells. Distance and trajectories covered by monocytes and $\mathrm{T}$ lymphocytes of healthy donors to Coxiella coated beads seems to be similar to that found in zebrafish; however, these were diminished if the monocytes and $\mathrm{T}$ lymphocytes came from patients with chronic Q fever. In addition, monocytes and $\mathrm{T}$ lymphocytes from chronic $\mathrm{Q}$ fever were either unable or displayed partial granuloma formation. The authors comment that their experiments recapitulate what happens in vivo since patients with acute $\mathrm{Q}$ fever form fibrin ring granulomas but as the infection becomes chronic the granulomas are defective and only spotty necrosis surrounded by collections of lymphocytes are observed.

\section{Conclusions}

Granulomatous inflammation is a complex immune reaction that includes both innate and adaptive immunity and can be caused by a variety of infectious agents. When the granuloma is caused by mycobacteria, disseminated disease has now been well documented using molecular methods. Molecular methods have also been very useful to define that not all granulomas with AFB are due to M. tuberculosis and that mycobacteria are sometimes found in the absence of bacilli. However, an etiology for granulomatous inflammation with or without necrosis is not always found, even with the use of molecular methods. Defining which granulomas need to be tested using molecular methods, which probes or primers and protocols to use routinely, and what is the ideal specimen is not clear at this point as the series presented vary largely in these aspects.

\section{References}

[1] L. Ramakrishnan, "Revisiting the role of the granuloma in tuberculosis," Nature Reviews Immunology, vol. 12, no. 5, pp. 352-366, 2012.

[2] L. W. Lamps, "Hepatic granulomas, with an emphasis on infectious causes," Advances in Anatomic Pathology, vol. 15, no. 6, pp. 309-318, 2008.

[3] B. Geramizadeh, R. Jahangid, and E. Moradi, "Causes of hepatic granuloma: a 12-year single center experience from Southern Iran," Archives of Iranian Medicine, vol. 14, pp. 288-289, 2011.

[4] S. Mukhopadhyay, "Role of histology in the diagnosis of infectious causes of granulomatous lung disease," Current Opinion in Pulmonary Medicine, vol. 17, no. 3, pp. 189-196, 2011.

[5] G. Psarros, J. Riddell, T. Gandhi, C. A. Kauffman, and S. K. Cinti, "Bartonella henselae infections in solid organ transplant recipients: report of 5 cases and review of the literature," Medicine, vol. 91, no. 2, pp. 111-121, 2012.

[6] J. Ollague-Sierra and J. Ollague-Torres, "New clinical and histological patterns of acute disseminated histoplasmosis in human immunodeficiency virus-positive patients with acquired immunodeficiency syndrome," American Journal of Dermatopathology. In press.

[7] C. Nopvichai, A. Sanpavat, R. Sawatdee et al., "PCR detection of Mycobacterium tuberculosis in necrotising non-granulomatous lymphadenitis using formalin-fixed paraffin-embedded tissue: a study in Thai patients," Journal of Clinical Pathology, vol. 62, no. 9, pp. 812-815, 2009.

[8] P. K. Ramdial, Y. Sing, S. Subrayan et al., "Granulomas in acquired immunodeficiency syndrome-associated cutaneous Kaposi sarcoma: evidence for a role for Mycobacterium tuberculosis," Journal of Cutaneous Pathology, vol. 37, no. 8, pp. 827-834, 2010.

[9] S. Akbulut, N. Sogutcu, and Y. Yagmur, "Coexistence of breast cancer and tuberculosis in axillary lymph nodes: a case report and literature review," Breast Cancer Research and Treatment, vol. 130, no. 3, pp. 1037-1042, 2011.

[10] P. H. Hartel, K. Shilo, M. Klassen-Fischer et al., "Granulomatous reaction to Pneumocystis jirovecii: clinicopathologic review of 20 cases," American Journal of Surgical Pathology, vol. 34, no. 5, pp. 730-734, 2010.

[11] H. Chang, L. Y. Shih, C. W. Wang, W. Y. Chuang, and C. C. Chen, "Granulomatous Pneumocystis jiroveci pneumonia in a patient with diffuse large b-cell lymphoma: case report and review of the literature," Acta Haematologica, vol. 123, no. 1, pp. 30-33, 2009.

[12] A. Totet, H. Duwat, G. Daste, A. Berry, R. Escamilla, and G. Nevez, "Pneumocystis jirovecii genotypes and granulomatous pneumocystosis," Medecine et Maladies Infectieuses, vol. 36, no. 4, pp. 229-231, 2006.

[13] L. D. Notarangelo, "Primary immunodeficiencies," Journal of Allergy and Clinical Immunology, vol. 125, no. 2, supplement 2, pp. S182-S194, 2010.

[14] M. A. Park, J. T. Li, J. B. Hagan, D. E. Maddox, and R. S. Abraham, "Common variable immunodeficiency: a new look at an old disease," The Lancet, vol. 372, no. 9637, pp. 489-502, 2008.

[15] D. G. James, "A clinicopathological classification of granulomatous disorders," Postgraduate Medical Journal, vol. 76, no. 898, pp. 457-465, 2000. 
[16] A. R. Travassos, J. Borges-Costa, J. Raposo, L. S. Almeida, and P. Filipe, "Recurrence of peripheral T-cell lymphoma as granulomas in the lower limbs," Anais Brasileiros de Dermatologia, vol. 87, no. 5, pp. 772-774, 2012.

[17] C. Rizzardi, M. Schneider, E. Barresi, A. Brollo, and M. Melato, "Metastasis of high grade renal cell carcinoma, clear cell type, in fibrous dysplasia with superimposed giant cell reparative granuloma," Pathologica, vol. 101, no. 6, pp. 240-243, 2009.

[18] D. T. Alexandrescu, N. H. Riordan, T. E. Ichim et al., "On the missing link between inflammation and cancer," Dermatology Online Journal, vol. 17, no. 1, article 10, 2011.

[19] D. P. Steinfort, A. Tsui, J. Grieve, M. L. Hibbs, G. P. Anderson, and L. B. Irving, "Sarcoidal reactions in regional lymph nodes of patients with early stage non-small cell lung cancer predict improved disease-free survival: a pilot case-control study," Human Pathology, vol. 43, no. 3, pp. 333-338, 2012.

[20] L. M. Heinzerling, M. D. Anliker, J. Müller, M. Schlaeppi, and R. von Moos, "Sarcoidosis induced by interferon- $\alpha$ in melanoma patients: incidence, clinical manifestations, and management strategies," Journal of Immunotherapy, vol. 33, no. 8, pp. 834-839, 2010.

[21] G. Berthod, R. Lazor, I. Letovanec et al., "Pulmonary sarcoidlike granulomatosis induced by ipilimumab," Journal of Clinical Oncology, vol. 30, no. 17, pp. e156-e159, 2012.

[22] H. A. Fuchs and S. B. Tanner, "Granulomatous disorders of the nose and paranasal sinuses," Current Opinion in Otolaryngology and Head and Neck Surgery, vol. 17, no. 1, pp. 23-27, 2009.

[23] K. A. Oswald-Richter and W. P. Drake, "The etiologic role of infectious antigens in sarcoidosis pathogenesis," Seminars in Respiratory and Critical Care Medicine, vol. 31, no. 4, pp. 375-379, 2010.

[24] S. M. Lagana, R. K. Moreira, and J. H. Lefkowitch, "Hepatic granulomas: pathogenesis and differential diagnosis," Clinics in Liver Disease, vol. 14, no. 4, pp. 605-617, 2010.

[25] A. Kilic, G. Metan, and E. Alp, "Clinical presentations and diagnosis of brucellosis," Recent Patents on Anti-Infective Drug Discovery. In press.

[26] J. D. Colmenero, P. Morata, J. D. Ruiz-Mesa et al., "Multiplex real-time polymerase chain reaction: a practical approach for rapid diagnosis of tuberculous and brucellar vertebral osteomyelitis," Spine, vol. 35, no. 24, pp. E1392-E1396, 2010.

[27] N. Turhan, M. Kurt, Y. O. Ozderin, and O. K. Kurt, "Hepatic granulomas: a clinicopathologic analysis of 86 cases," Pathology Research and Practice, vol. 207, no. 6, pp. 359-365, 2011.

[28] M. El-Khalawany, I. Meraag, B. Eassa, and H. H. El-Naby, "Clinicopathological features and the practice of diagnosing infectious cutaneous granulomas in Egypt," International Journal of Infectious Diseases, vol. 15, no. 9, pp. e620-e626, 2011.

[29] A. R. Zink, W. Grabner, and A. G. Nerlich, "Molecular identification of human tuberculosis in recent and historic bone tissue samples: the role of molecular techniques for the study of historic tuberculosis," American Journal of Physical Anthropology, vol. 126, no. 1, pp. 32-47, 2005.

[30] J. Y. W. Li, S. T. H. Lo, and C. S. Ng, "Molecular detection of Mycobacterium tuberculosis in tissues showing granulomatous inflammation without demonstrable acid-fast bacilli," Diagnostic Molecular Pathology, vol. 9, no. 2, pp. 67-74, 2000.

[31] J. S. Park, Y. A. Kang, S. Y. Kwon et al., "Nested PCR in lung tissue for diagnosis of pulmonary tuberculosis," European Respiratory Journal, vol. 35, no. 4, pp. 851-857, 2010.
[32] A. R. Zink and A. G. Nerlich, "Molecular strain identification of the Mycobacterium tuberculosis complex in archival tissue samples," Journal of Clinical Pathology, vol. 57, no. 11, pp. 1185-1192, 2004.

[33] A. L. S. Amand, D. N. Frank, M. A. de-Groote, R. J. Basaraba, I. M. Orme, and N. R. Pace, "Use of specific rRNA oligonucleotide probes for microscopic detection of Mycobacterium tuberculosis in culture and tissue specimens," Journal of Clinical Microbiology, vol. 43, no. 10, pp. 5369-5371, 2005.

[34] N. Nakano, R. Wada, N. Yajima, N. Yamamoto, Y. Wakai, and H. Otsuka, "Mycobacterial infection of the musculoskeletal tissues: the use of pathological specimens for identification of causative species by PCR-direct sequencing of $16 \mathrm{~S}$ rDNA," Japanese Journal of Infectious Diseases, vol. 63, no. 3, pp. 188-191, 2010.

[35] S. Schulz, A. D. Cabras, M. Kremer et al., "Species identification of Mycobacteria in paraffin-embedded tissues: frequent detection of nontuberculous Mycobacteria," Modern Pathology, vol. 18, no. 2, pp. 274-282, 2005.

[36] S. Kulkarni, S. Vyas, A. Supe, and G. Kadival, "Use of polymerase chain reaction in the diagnosis of abdominal tuberculosis," Journal of Gastroenterology and Hepatology, vol. 21, no. 5, pp. 819-823, 2006.

[37] P. Mahaisavariya, A. Chaiprasert, J. Manonukul, S. Khemngern, and N. Tingtoy, "Detection and identification of Mycobacterium species by polymerase chain reaction (PCR) from paraffinembedded tissue compare to AFB staining in pathological sections," Journal of the Medical Association of Thailand, vol. 88, no. 1, pp. 108-113, 2005.

[38] D. Kidane, J. O. Olobo, A. Habte et al., "Identification of the causative organism of tuberculous lymphadenitis in Ethiopia by PCR," Journal of Clinical Microbiology, vol. 40, no. 11, pp. 4230-4234, 2002.

[39] M. Lefmann, B. Schweickert, P. Buchholz et al., "Evaluation of peptide nucleic acid-fluorescence in situ hybridization for identification of clinically relevant Mycobacteria in clinical specimens and tissue sections," Journal of Clinical Microbiology, vol. 44, no. 10, pp. 3760-3767, 2006.

[40] M. G. Sumi, A. Mathai, R. Sheela et al., "Diagnostic utility of polymerase chain reaction and immunohistochemical techniques for the laboratory diagnosis of intracranial tuberculoma," Clinical Neuropathology, vol. 20, no. 4, pp. 176-180, 2001.

[41] J. S. Pedersen, I. Clarke, and J. Mills, "Improved detection of Mycobacteria species in formalin-fixed tissue sections," Histopathology, vol. 59, no. 5, pp. 993-1005, 2011.

[42] D. Y. Park, J. Y. Kim, K. U. Choi et al., "Comparison of polymerase chain reaction with histopathologic features for diagnosis of tuberculosis in formalin-fixed, paraffin-embedded histologic specimens," Archives of Pathology and Laboratory Medicine, vol. 127, no. 3, pp. 326-330, 2003.

[43] E. Quirós, A. Bettinardi, A. Quirós, G. Piédrola, and M. C. Maroto, "Detection of mycobacterial DNA in papulonecrotic tuberculid lesions by polymerase chain reaction," Journal of Clinical Laboratory Analysis, vol. 14, no. 4, pp. 133-135, 2000.

[44] K. Chawla, S. Gupta, C. Mukhopadhyay, P. S. Rao, and S. S. Bhat, "PCR for M. tuberculosis in tissue samples," Journal of Infection in Developing Countries, vol. 3, no. 2, pp. 83-87, 2009.

[45] G. M. Taylor, D. R. Worth, S. Palmer, K. Jahans, and R. G. Hewinson, "Rapid detection of Mycobacterium bovis DNA in cattle lymph nodes with visible lesions using PCR," $B M C$ Veterinary Research, vol. 3, article 12, 2007. 
[46] E. Selva, V. Hofman, F. Berto et al., "The value of polymerase chain reaction detection of Mycobacterium tuberculosis in granulomas isolated by laser capture microdissection," Pathology, vol. 36, no. 1, pp. 77-81, 2004.

[47] C. H. Hsiao, Y. T. Lin, C. C. Lai, C. H. Chou, and P. R. Hsueh, "Identification of nontuberculous mycobacterial infection by IS6110 and hsp65 gene analysis on lung tissues," Diagnostic Microbiology and Infectious Disease, vol. 68, no. 3, pp. 241-246, 2010.

[48] K. Nakanaga, Y. Hoshino, M. Wakabayashi et al., "Mycobacterium shigaense sp. nov., a novel slowly growing scotochromogenic mycobacterium that produced nodules in an erythroderma patient with severe cellular immunodeficiency and a history of Hodgkin's disease," Journal of Dermatology, vol. 39, no. 4, pp. 389-396, 2012.

[49] A. Y. Chuang, M. H. Tsou, S. J. Chang et al., "Mycobacterium abscessus granulomatous prostatitis," American Journal of Surgical Pathology, vol. 36, no. 3, pp. 418-422, 2012.

[50] M. Kaevska, I. Slana, P. Kralik et al., “Mycobacterium avium subsp. hominissuis' in neck lymph nodes of children and their environment examined by culture and triplex quantitative realtime PCR," Journal of Clinical Microbiology, vol. 49, no. 1, pp. 167-172, 2011.

[51] F. G. N. Rosado, C. W. Stratton, and C. A. Mosse, "Clinicopathologic correlation of epidemiologic and histopathologic features of pediatric bacterial lymphadenitis," Archives of Pathology and Laboratory Medicine, vol. 135, no. 11, pp. 1490-1493, 2011.

[52] P. Zhao, Y. Y. Zhang, Y. B. Li, Y. Zhu, and K. L. Wan, "Diagnosis of pulmonary disease caused by Mycobacterium abscessus: a case report," Journal of International Medical Research, vol. 39, no. 3, pp. 968-975, 2011.

[53] L. S. B. van Coppenraet, V. T. H. B. M. Smit, K. E. Templeton, E. C. J. Claas, and E. J. Kuijper, "Application of real-time PCR to recognize atypical Mycobacteria in archival skin biopsies: high prevalence of Mycobacterium haemophilum," Diagnostic Molecular Pathology, vol. 16, no. 2, pp. 81-86, 2007.

[54] S. K. P. Lau, S. O. T. Curreem, A. H. Y. Ngan, C. K. Yeung, K. Y. Yuen, and P. C. Y. Woo, "First report of disseminated Mycobacterium skin infections in two liver transplant recipients and rapid diagnosis by hsp65 gene sequencing," Journal of Clinical Microbiology, vol. 49, no. 11, pp. 3733-3738, 2011.

[55] R. van-Hest, A. van-der-Zanden, M. Boeree et al., "Mycobacterium heckeshornense infection in an immunocompetent patient and identification by $16 \mathrm{~S}$ rRNA sequence analysis of culture material and a histopathology tissue specimen," Journal of Clinical Microbiology, vol. 42, no. 9, pp. 4386-4389, 2004.

[56] N. D. Bills, S. H. Hinrichs, T. A. Aden, R. S. Wickert, and P. C. Iwen, "Molecular identification of Mycobacterium chimaera as a cause of infection in a patient with chronic obstructive pulmonary disease," Diagnostic Microbiology and Infectious Disease, vol. 63, no. 3, pp. 292-295, 2009.

[57] S. Al Dahouk and K. Nöckler, "Implications of laboratory diagnosis on brucellosis therapy," Expert Review of Anti-Infective Therapy, vol. 9, no. 7, pp. 833-845, 2011.

[58] L. W. Lamps, J. M. Havens, A. Sjostedt, D. L. Page, and M. A. Scott, "Histologic and molecular diagnosis of tularemia: a potential bioterriorism agent endemic to North America," Modern Pathology, vol. 17, no. 5, pp. 489-495, 2004.

[59] M. Maurin, I. Pelloux, J. P. Brion, J.-N. Del Banõ, and A. Picard, "Human tularemia in France, 2006-2010," Clinical Infectious Diseases, vol. 53, no. 10, pp. e133-e141, 2011.
[60] C. P. Tamboli, M. R. Good, E. M. Reynolds, P. Sharma, and F. A. Mitros, "Anti-Yersinia antibodies are not associated with microscopic colitis in an American case-control study," Scandinavian Journal of Gastroenterology, vol. 46, no. 12, pp. 1442-1448, 2011.

[61] R. Stephan, N. Cernela, D. Ziegler et al., "Rapid species specifc identifcation and subtyping of Yersinia enterocolitica by MALDI-TOF mass spectrometry," Journal of Microbiological Methods, vol. 87, no. 2, pp. 150-153, 2011.

[62] H. Müller, K. Eisendle, W. Bräuninger, H. Kutzner, L. Cerroni, and B. Zelger, "Comparative analysis of immunohistochemistry, polymerase chain reaction and focus-floating microscopy for the detection of Treponema pallidum in mucocutaneous lesions of primary, secondary and tertiary syphilis," British Journal of Dermatology, vol. 165, no. 1, pp. 50-60, 2011.

[63] W. Behrhof, E. Springer, W. Bräuninger, C. J. Kirkpatrick, and A. Weber, "PCR testing for Treponema pallidum in paraffinembedded skin biopsy specimens: test design and impact on the diagnosis of syphilis," Journal of Clinical Pathology, vol. 61, no. 3, pp. 390-395, 2008.

[64] G. F. Cota, M. R. de Sousa, F. N. Demarqui, and A. Rabello, "The diagnostic accuracy of serologic and molecular methods for detecting visceral leishmaniasis in HIV infected patients: meta-analysis," PLoS Neglected Tropical Diseases, vol. 6, no. 5, Article ID e1665, 2012.

[65] H. Goto and J. A. L. Lindoso, "Cutaneous and mucocutaneous leishmaniasis," Infectious Disease Clinics of North America, vol. 26, no. 2, pp. 293-307, 2012.

[66] L. Yehia, M. Adib-Houreih, W. F. Raslan et al., "Molecular diagnosis of cutaneous leishmaniasis and species identification: analysis of 122 biopsies with varied parasite index," Journal of Cutaneous Pathology, vol. 39, no. 3, pp. 347-355, 2012.

[67] R. V. de Andrade, M. N. B. de Lucena, L. C. L. Ferreira et al., "The use of polymerase chain reaction to confirm diagnosis in skin biopsies consistent with American tegumentary leishmaniasis at histopathology: a study of 90 cases," Anais Brasileiros de Dermatologia, vol. 86, no. 5, pp. 892-896, 2011.

[68] F. Robert-Gangneux and M.-L. Dardé, "Epidemiology of and diagnostic strategies for toxoplasmosis," Clinical Microbiology Reviews, vol. 25, no. 2, pp. 264-296, 2012.

[69] G. Saadatnia and M. Golkar, "A review on human toxoplasmosis," Scandinavian Journal of Infectious Diseases, vol. 44, no. 11, pp. 805-814, 2012.

[70] O. Villard, B. Cimon, J. Franck et al., "Evaluation of the usefulness of six commercial agglutination assays for serologic diagnosis of toxoplasmosis," Diagnostic Microbiology and Infectious Disease, vol. 73, no. 3, pp. 231-235, 2012.

[71] G. Akpek, A. Uslu, T. Huebner et al., "Granulomatous amebic encephalitis: an under-recognized cause of infectiousmortality after hematopoietic stemcell transplantation," Transplant Infectious Disease, vol. 13, no. 4, pp. 366-373, 2011.

[72] J. Guarner, J. Bartlett, W. J. Shieh, C. D. Paddock, G. S. Visvesvara, and S. R. Zaki, "Histopathologic spectrum and immunohistochemical diagnosis of amebic meningoencephalitis," Modern Pathology, vol. 20, no. 12, pp. 1230-1237, 2007.

[73] K. Khairnar, G. S. Tamber, F. Ralevski, and D. R. Pillai, "Comparison of molecular diagnostic methods for the detection of Acanthamoeba spp. from clinical specimens submitted for keratitis," Diagnostic Microbiology and Infectious Disease, vol. 70, no. 4, pp. 499-506, 2011.

[74] P. Goldschmidt, S. Degorge, D. Benallaoua, L. Batellier, D. DiCave, and C. Chaumeil, "Rapid detection and simultaneous 
molecular profile characterization of Acanthamoeba infections," Diagnostic Microbiology and Infectious Disease, vol. 74, no. 2, pp. 137-141, 2012.

[75] B. Gryseels, "Schistosomiasis," Infectious Disease Clinics of North America, vol. 26, no. 2, pp. 383-397, 2012.

[76] M. G. Cavalcanti, M. M. I. Gonçalves, M. M. Barreto et al., "Genital schistosomiasis mansoni concomitant to genital tumor in areas of low endemicity: challenging diagnosis," Brazilian Journal of Infectious Diseases, vol. 15, no. 2, pp. 174-177, 2011.

[77] M. J. Enk, G. Oliveira e Silva, and N. B. Rodrigues, "Diagnostic accuracy and applicability of a PCR system for the detection of Schistosoma mansoni DNA in human urine samples from an endemic area," PLoS ONE, vol. 7, no. 6, Article ID e38947, 2012.

[78] H. F. Kinkel, S. Dittrich, B. Baümer, and T. Weitzel, "Evaluation of eight serological tests for diagnosis of imported schistosomiasis," Clinical and Vaccine Immunology, vol. 19, no. 6, pp. 948-953, 2012.

[79] T. H. Le, K. T. Nguyen, N. T. B. Nguyen et al., "Development and evaluation of a single-step duplex PCR for simultaneous detection of Fasciola hepatica and Fasciola gigantica (family Fasciolidae, class Trematoda, phylum Platyhelminthes)," Journal of Clinical Microbiology, vol. 50, no. 8, pp. 2720-2726, 2012.

[80] M. A. Valero, M. V. Periago, I. Pérez-Crespo et al., "Assessing the validity of an ELISA test for the serological diagnosis of human fascioliasis in different epidemiological situations," Tropical Medicine and International Health, vol. 17, no. 5, pp. 630-636, 2012.

[81] Z. A. Demerdash, T. M. Diab, I. R. Aly et al., "Diagnostic efficacy of monoclonal antibody based sandwich enzyme linked immunosorbent assay (ELISA) for detection of Fasciola gigantica excretory/secretory antigens in both serum and stool," Parasites and Vectors, vol. 4, no. 1, pp. 176-183, 2011.

[82] S. Mattiucci, M. Paoletti, F. Borrini et al., "First molecular identification of the zoonotic parasite Anisakis pegreffii (Nematoda: Anisakidae) in a paraffin-embedded granuloma taken from a case of human intestinal anisakiasis in Italy," BMC Infectious Diseases, vol. 11, article 82, 2011.

[83] J. Kim, J. O. Jo, S. H. Choi et al., "Seroprevalence of antibodies against anisakis simplex larvae among health-examined residents in three hospitals of Southern parts of Korea," Korean Journal of Parasitology, vol. 49, no. 2, pp. 139-144, 2011.

[84] J. Guarner and M. E. Brandt, "Histopathologic diagnosis of fungal infections in the 21st century," Clinical Microbiology Reviews, vol. 24, no. 2, pp. 247-280, 2011.

[85] L. R. McTaggart, N. L. Wengenack, and S. E. Richardson, "Validation of the mycAssay pneumocystis kit for detection of Pneumocystis jirovecii in bronchoalveolar lavage specimens by comparison to a laboratory standard of direct immunofluorescence microscopy, real-time PCR, or conventional PCR," Journal of Clinical Microbiology, vol. 50, no. 6, pp. 1856-1859, 2012.

[86] S. le Gal, C. Damiani, A. Rouillé et al., "A cluster of Pneumocystis infections among renal transplant recipients: molecular evidence of colonized patients as potential infectious sources of Pneumocystis jirovecii," Clinical Infectious Diseases, vol. 54, no. 7, pp. e62-e71, 2012.

[87] D. E. Karageorgopoulos, J. M. Qu, I. P. Korbila, Y.-G. Zhu, V. A. Vasileiou, and M. E. Falagas, "Accuracy of $\beta$-d-glucan for the diagnosis of Pneumocystis jirovecii pneumonia: a metaanalysis," Clinical Microbiology and Infection, vol. 19, no. 1, pp. 39-49, 2013.
[88] S. A. Koepsell, S. H. Hinrichs, and P. C. Iwen, "Applying a realtime PCR assay for Histoplasma capsulatum to clinically relevant formalin-fixed paraffin-embedded human tissue," Journal of Clinical Microbiology, vol. 50, no. 10, pp. 3395-3397, 2012.

[89] N. E. Babady, S. P. Buckwalter, L. Hall, K. M. Le Febre, M. J. Binnicker, and N. L. Wengenack, "Detection of Blastomyces dermatitidis and Histoplasma capsulatum from culture isolates and clinical specimens by use of real-time PCR," Journal of Clinical Microbiology, vol. 49, no. 9, pp. 3204-3208, 2011.

[90] P. Connolly, C. A. Hage, J. R. Bariola et al., "Blastomyces dermatitidis antigen detection by quantitative enzyme immunoassay," Clinical and Vaccine Immunology, vol. 19, no. 1, pp. 53-56, 2012.

[91] O. Welsh, L. Vera-Cabrera, A. Rendon, G. Gonzalez, and A. Bonifaz, "Coccidioidomycosis," Clinics in Dermatology, vol. 30, no. 6, pp. 573-591, 2012.

[92] G. R. Thompson, J. M. Lunetta, S. M. Johnson et al., "Early treatment with fluconazole may abrogate the development of IgG antibodies in coccidioidomycosis," Clinical Infectious Diseases, vol. 53, no. 6, pp. e20-e24, 2011.

[93] D. Vucicevic, J. E. Blair, M. J. Binnicker et al., "The utility of Coccidioides polymerase chain reaction testing in the clinical setting," Mycopathologia, vol. 170, no. 5, pp. 345-351, 2010.

[94] R. S. de-Freitas, K. C. Dantas, R. S. P. Garcia, M. M. C. Magri, and H. F. de-Andrade, "Paracoccidioides brasiliensis causing a rib lesion in an adult AIDS patient," Human Pathology, vol. 41, no. 9, pp. 1350-1354, 2010.

[95] F. R. R. Teles and M. L. Martins, "Laboratorial diagnosis of paracoccidioidomycosis and new insights for the future of fungal diagnosis," Talanta, vol. 85, no. 5, pp. 2254-2264, 2011.

[96] M. C. Z. Perenha-Viana, I. A. A. Gonzales, S. R. Brockelt, L. N. C. Machado, and T. I. E. Svidzinski, "Serological diagnosis of paracoccidioidomycosis through a Western blot technique," Clinical and Vaccine Immunology, vol. 19, no. 4, pp. 616-619, 2012.

[97] D. A. Relman, T. M. Schmidt, R. P. MacDermott, and S. Falkow, "Identification of the uncultured bacillus of Whipple's disease," The New England Journal of Medicine, vol. 327, no. 5, pp. 293-301, 1992.

[98] D. A. Relman, P. W. Lepp, K. N. Sadler, and T. M. Schmidt, "Phylogenetic relationships among the agent of bacillary angiomatosis, Bartonella bacilliformis, and other alphaproteobacteria," Molecular Microbiology, vol. 6, no. 13, pp. 1801-1807, 1992.

[99] V. Rickerts, G. Just-Nübling, F. Konrad et al., "Diagnosis of invasive aspergillosis and mucormycosis in immunocompromised patients by seminested PCR assay of tissue samples," European Journal of Clinical Microbiology and Infectious Diseases, vol. 25, no. 1, pp. 8-13, 2006.

[100] A. Lau, S. Chen, T. Sorrell et al., "Development and clinical application of a panfungal PCR assay to detect and identify fungal DNA in tissue specimens," Journal of Clinical Microbiology, vol. 45, no. 2, pp. 380-385, 2007.

[101] C. Muñoz-Cadavid, S. Rudd, S. R. Zaki et al., "Improving molecular detection of fungal DNA in formalin-fixed paraffinembedded tissues: comparison of five tissue DNA extraction methods using panfungal PCR," Journal of Clinical Microbiology, vol. 48, no. 6, pp. 2147-2153, 2010.

[102] I. Brownell, F. Ramiŕez-Valle, M. Sanchez, and S. Prystowsky, "Evidence for Mycobacteria in sarcoidosis," American Journal of Respiratory Cell and Molecular Biology, vol. 45, no. 5, pp. 899-905, 2011. 
[103] W. P. Drake, Z. Pei, D. T. Pride, R. D. Collins, T. L. Cover, and M. J. Blaser, "Molecular analysis of sarcoidosis tissues for Mycobacterium species DNA," Emerging Infectious Diseases, vol. 8, no. 11, pp. 1334-1341, 2002.

[104] Y. Zhou, H. P. Li, Q. H. Li et al., "Differentiation of sarcoidosis from tuberculosis using real-time PCR assay for the detection and quantification of Mycobacterium tuberculosis," Sarcoidosis Vasculitis and Diffuse Lung Diseases, vol. 25, no. 2, pp. 93-99, 2008.

[105] Z. Song, L. Marzilli, B. M. Greenlee et al., "Mycobacterial catalase-peroxidase is a tissue antigen and target of the adaptive immune response in systemic sarcoidosis," Journal of Experimental Medicine, vol. 201, no. 5, pp. 755-767, 2005.

[106] H. Ichikawa, M. Kataoka, J. Hiramatsu et al., "Quantitative analysis of propionibacterial DNA in bronchoalveolar lavage cells from patients with sarcoidosis," Sarcoidosis Vasculitis and Diffuse Lung Diseases, vol. 25, no. 1, pp. 15-20, 2008.

[107] D. Steensels, J. Verhaegen, and K. Lagrou, "Matrix-assisted laser desorption ionization-time of flight mass spectrometry for the identification of bacteria and yeasts in a clinical microbiology laboratory: a review," Acta Clinica Belgica, vol. 66, pp. 267-273, 2011.

[108] K. Sogawa, M. Watanabe, K. Sato et al., "Use of the MALDI BioTyper system with MALDI-TOF mass spectrometry for rapid identification of microorganisms," Analytical and Bioanalytical Chemistry, vol. 400, no. 7, pp. 1905-1911, 2011.

[109] A. A. Ghavanini and D. G. Munoz, "Intracranial caseating granulomas with no infectious organism detected," Canadian Journal of Neurological Sciences, vol. 38, no. 1, pp. 82-87, 2011.

[110] J. Zuñiga, D. Torres-García, T. Santos-Mendoza, T. S. Rodriguez-Reyna, J. Granados, and E. J. Yunis, "Cellular and humoral mechanisms involved in the control of tuberculosis," Clinical and Developmental Immunology, vol. 2012, Article ID 193923, 18 pages, 2012.

[111] F. G. C. Abath, C. N. L. Morais, C. E. L. Montenegro, T. A. Wynn, and S. M. L. Montenegro, "Immunopathogenic mechanisms in schistosomiasis: what can be learnt from human studies?" Trends in Parasitology, vol. 22, no. 2, pp. 85-91, 2006.

[112] R. Appelberg, "Neutrophils and intracellular pathogens: beyond phagocytosis and killing," Trends in Microbiology, vol. 15, no. 2, pp. 87-92, 2007.

[113] T. D. Bold and J. D. Ernst, "Who benefits from granulomas, Mycobacteria or host?" Cell, vol. 136, no. 1, pp. 17-19, 2009.

[114] R. L. Hunter, "Pathology of post primary tuberculosis of the lung: an illustrated critical review," Tuberculosis, vol. 91, no. 6, pp. 497-509, 2011.

[115] J. Barrios-Payán, M. Saqui-Salces, M. Jeyanathan et al., "Extrapulmonary locations of Mycobacterium tuberculosis DNA during latent infection," Journal of Infectious Diseases, vol. 206, no. 8, pp. 1194-1205, 2012.

[116] H. D. Donoghue, "Insights gained from palaeomicrobiology into ancient and modern tuberculosis," Clinical Microbiology and Infection, vol. 17, no. 6, pp. 821-829, 2011.

[117] J. L. Taylor, J. M. Hattle, S. A. Dreitz et al., "Role for matrix metalloproteinase 9 in granuloma formation during pulmonary Mycobacterium tuberculosis infection," Infection and Immunity, vol. 74, no. 11, pp. 6135-6144, 2006.

[118] D. G. Russell, "Mycobacterium tuberculosis and the intimate discourse of a chronic infection," Immunological Reviews, vol. 240, no. 1, pp. 252-268, 2011.
[119] M. J. Kim, H. C. Wainwright, M. Locketz et al., "Caseation of human tuberculosis granulomas correlates with elevated host lipid metabolism," EMBO Molecular Medicine, vol. 2, no. 7, pp. 258-274, 2010.

[120] M. E. Onwuamaegbu, R. A. Belcher, and C. Soare, "Cell walldeficient bacteria as a cause of infections: a review of the clinical significance," Journal of International Medical Research, vol. 33, no. 1, pp. 1-20, 2005.

[121] S. T. Brown, I. Brett, P. L. Almenoff, M. Lesser, M. Terrin, and A. S. Teirstein, "Recovery of cell wall-deficient organisms from blood does not distinguish between patients with sarcoidosis and control subjects," Chest, vol. 123, no. 2, pp. 413-417, 2003.

[122] K. Hibiya, E. Shigeto, K. Iida et al., "Distribution of mycobacterial antigen based on differences of histological characteristics in pulmonary Mycobacterium avium infectious diseases-consideration of the extent of surgical resection from the pathological standpoint," Pathology Research and Practice, vol. 208, no. 1, pp. 53-58, 2012.

[123] M. S. Wilson, M. M. Mentink-Kane, J. T. Pesce, T. R. Ramalingam, R. Thompson, and T. A. Wynn, "Immunopathology of schistosomiasis," Immunology and Cell Biology, vol. 85, no. 2, pp. 148-154, 2007.

[124] A. Delaby, L. Gorvel, L. Espinosa et al., "Defective monocyte dynamics in Q fever granuloma deficiency," Journal of Infectious Diseases, vol. 205, no. 7, pp. 1086-1094, 2012. 


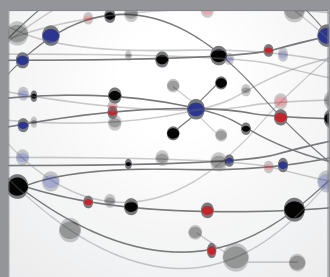

The Scientific World Journal
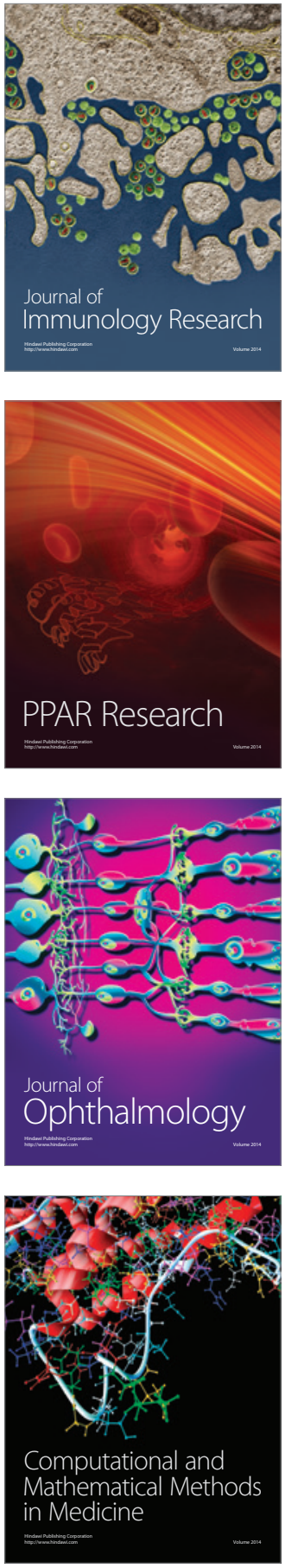

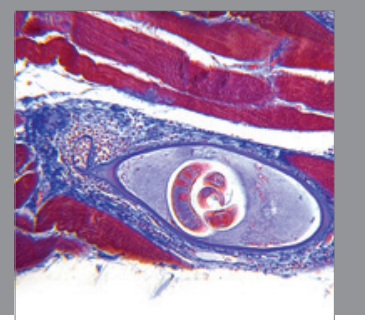

Gastroenterology

Research and Practice
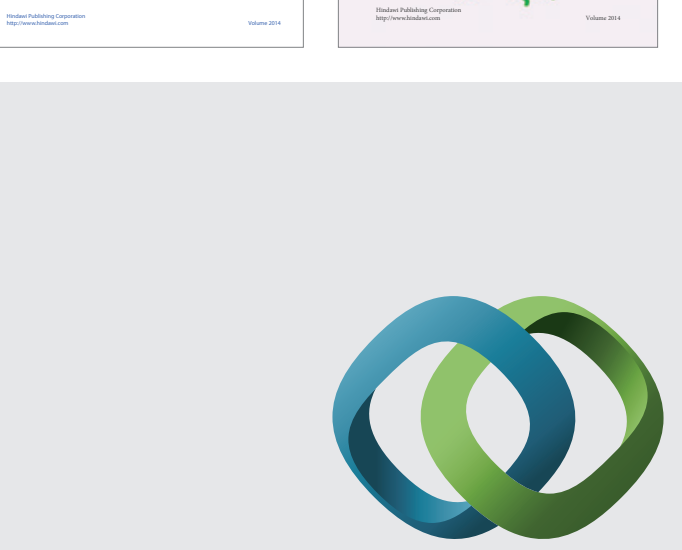

\section{Hindawi}

Submit your manuscripts at

http://www.hindawi.com
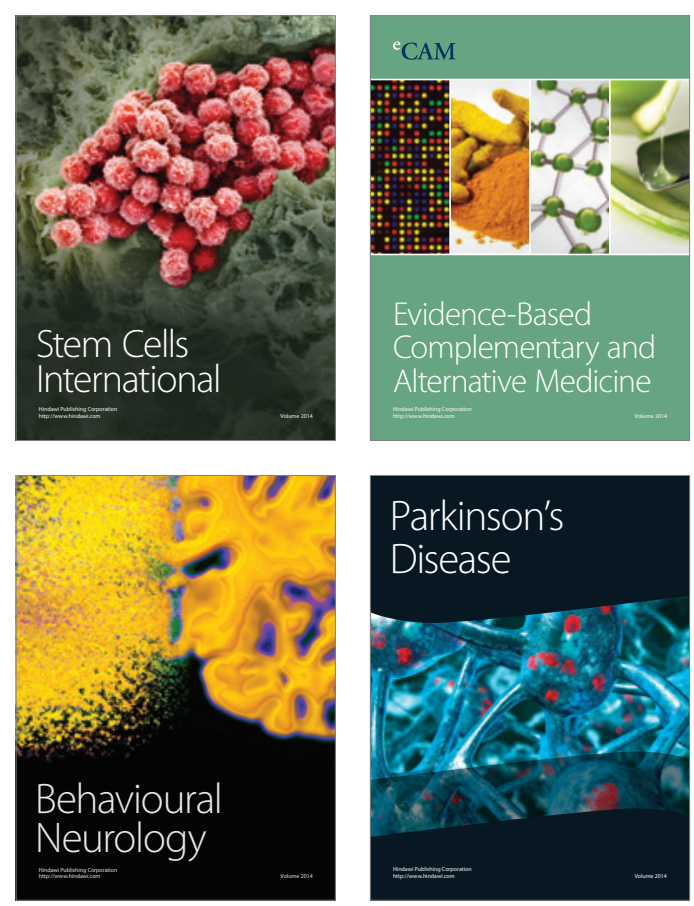

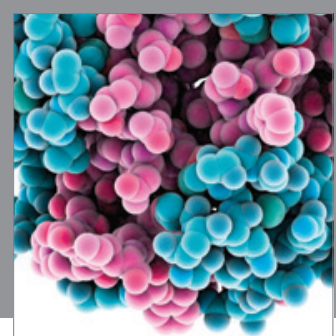

Journal of
Diabetes Research

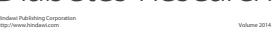

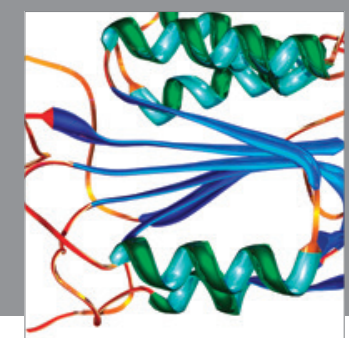

Disease Markers
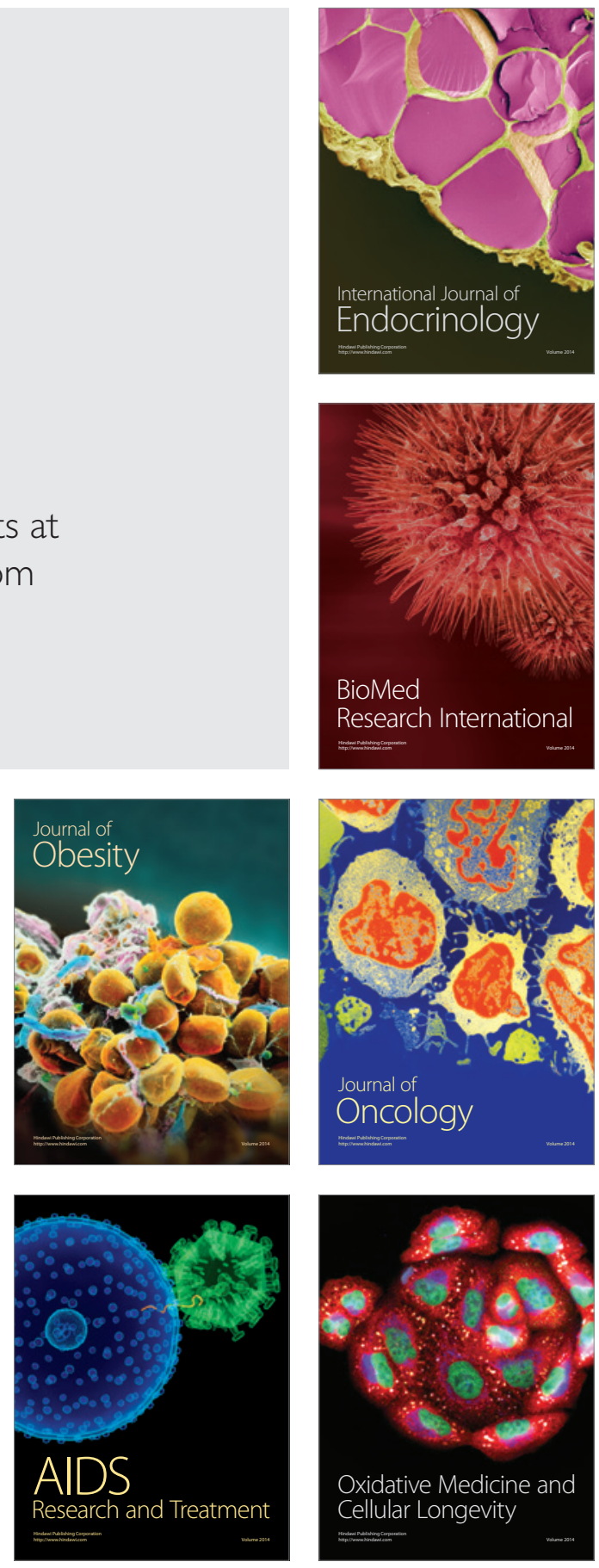